\title{
PANDANGAN SYED MUHAMMAD NAQUIB AL-ATTAS TENTANG ISLAMISASI ILMU
}

\author{
Oleh: \\ Ghazi Abdullah Muttaqien \\ Pesantren Persatuan Islam 19 Garut (Islamic Boarding School), address: Jl. Guntur \\ No.156 A/688 Garut, Jawa Barat, Indonesia. \\ Email: ghazimuttaqien19@gmail.com
}

\begin{abstract}
Abstrak
Penelitian ini bertujuan untuk mengkaji dan menyelidiki gagasan Islamisasi ilmu pengetahuan kontemporer dalam pandangan Syed Muhammad Naquib al-Attas. Metode deskriptif dengan pendekatan filsafat dipilih untuk penelitian ini. Dengan menafsirkan berbagai sumber, disimpulkan bahwa sejak awal kelahirannya, wacana Islamisasi ilmu telah menarik perhatian para ulama dan sebagian cendekiawan di dunia untuk membahasnya. Mereka yang terlibat dalam maudhu '(wacana) islamisasi ilmu, biasanya memperdebatkan pentingnya islamisasi ilmu mengingat suatu ilmu memiliki nilai yang sarat dengan apa yang diklaimnya, salah satu penyebabnya suatu ilmu atau ilmu pengetahuan disusupi oleh Pandangan dunia Barat yaitu sudut pandang sekuler, filosofi hidup mereka, serta nilai-nilai ideologi Barat yang pasti bertentangan dengan ajaran dan nilai Islam pula. Menurut penilaian mereka, ilmu yang berkembang saat ini sudah tidak bermanfaat lagi bagi umat manusia. Justru yang telah menyebabkan kehancuran dan malapetaka umat manusia. Sebagai cendekiawan Muslim kontemporer dan juga tokoh sentral dalam ide Islamisasi ilmu, Syed Muhammad Naquib al-Attas dengan berani menggemakan gagasan tersebut. Bahwa oleh karena itu Islamisasi ilmu bertujuan untuk mengembalikan ilmu yang dinilai telah keluar dari kerangka aksiologisnya.
\end{abstract}

Kata kunci: S.M.N. al-Attas, Islamisasi Ilmu, Pandangan Dunia Islam, dan. Epistemologi Islam.

\section{Abstract}

The aim of this paper is to examine and to investigate the idea of Islamization of contemporary knowledge in the view of Syed Muhammad Naquib al-Attas. Descriptive method with philosophy approach is choosen for this research. By the interpreting many resources, it concluded that from the beginning of its birth, the discourse of Islamization of knowledge has attracted the attention of scholars and 
some of intellectuals in the world to discuss it. Those who are involved in maudhu' (discourse) of Islamization of knowledge, usually argue about the importance of Islamization of knowledge considering that a science has a value laden according to what that claim, one of the reason that a science or knowledge is infiltrated by Western's worldview namely a secular point of view, their philosophy of life, as well as the values of Western ideology that are certainty contradictory to Islamic teachings and values as well. According to their judgment, the knowledge that is developing today is no longer the benefit to humanity. It is precisely that has led to the destruction and the catastrophe of the human race. As a contemporary Muslim scholar and also a central figure in the idea of Islamization of knowledge, Syed Muhammad Naquib al-Attas boldly echoed these ideas. That accordingly the Islamization of science aims to restore knowledge which is judged to have come out of its axiological framework.

Keywords: S.M.N. al-Attas, Islamization of knowledge, Islamic Worldview, and. Islamic epistemology.

\section{A. Pendahuluan}

Sepanjang sejarahnya, manusia telah menghadapi banyak tantangan dan kekacauan. Tetapi, belum pernah mereka menghadapi tantangan yang lebih serius daripada yang ditimbulkan oleh peradaban Barat saat ini. ${ }^{1}$ Prof. Syed Muhammad Naquib al-Attas, seorang pemikir yang dikenal cukup baik oleh dunia pemikiran Barat maupun Islam, memandang problem terberat yang dihadapi manusia dewasa ini adalah hegemoni dan dominasi keilmuan sekular Barat yang mengarah pada kehancuran umat manusia. ${ }^{2}$ Syed Muhammad Naquib al-Attas, menyatakan;

"Many challenges have arisen in the midst of man's confusion throughout the eges, but none perhaphs more serious and deconstructive to man than today's challenge posed by Western civilization." ${ }^{3}$

"Telah banyak tantangan yang muncul di tengah-tengah kekeliruan manusia sepanjang sejarah, tetapi barangkali tidak ada yang lebih serius dan lebih merusak terhadap manusia daripada tantangan yang dibawa peradaban Barat hari ini." ${ }^{\prime \prime}$

\footnotetext{
${ }^{1}$ Syed Muhammad Naquib al-Attas, Islam and Secularism, [Kuala Lumpur: ISTAC, 1995], hlm. 134-137).

${ }^{2}$ Adian Husaini, Wajah Peradaban barat: Dari Hegemoni Kristen ke Dominasi Sekular-Liberal, (Jakarta: GEMA INSANI, 2005), hlm. 3.

3 Syed Muhammad Naquib al-Attas, Islam, Secularism, And the Philosophy of The Future, (London \&New York: Mansell publishing Limited, 1985), hlm. 127.
} 
Teori ilmu yang berkembang pada saat ini menunjukan telah terjadi perceraian antara ilmu dan agama. Dengan berbagai penemuan ilmiah dan semangat kemajuan zaman, agama di Barat tidak lagi terkait dengan ilmu pengetahuan. Dampak peradaban Barat yang hegemonik menyebabkan ilmu pengetahuan menjadi sekular. Dalam pandangan Islam, ilmu adalah ibadah dan bagian yang inheren dengan agama. ${ }^{5}$

Dewasa ini, peradaban Barat yang berlandaskan pada paham sekularisme dan materialisme telah membawa dunia menuju ambang kehancuran. Memang tidak menutup mata berbagai keberhasilan dan kemajuan dihasilkan oleh peradaban ini. Namun juga tidak dapat dipungkiri peradaban Barat juga telah menghasilkan penjajahan, perang berkepanjangan, ketimpangan sosial, kerusakan lingkungan, keterasingan (Alienasi), dan anomie (berkurangnya adat sosial atau standar etika dalam lini indifidu atau masyarakat). Sehingga tidak terdapat keseimbangan dan ketertiban di masyarakat. ${ }^{6}$

Mendiagnosa 'Virus' yang terkandung dalam westernisasi ilmu, Syed Muhammad Naquib al-Attas mengobatinya dengan Islamisasi ilmu. ${ }^{7}$ Mengenai hal ini Naquib al-Attas ber-hujjah, bahwa tantangan terbesar yang dihadapi kaum muslimin adalah ilmu pengetahuan modern yang tidak netral dan telah diinfus kedalam praduga-praduga agama, budaya dan filosofis, yang sebenarnya berasal dari refleksi kesadaran dan pengalaman manusia Barat, Sehingga permasalahan ilmu pengetahuan tersebut menyebabkan berbagai problematika di dalam masyarakat, khususnya Umat Islam. Maka, ilmu pengetahuan modern harus diislamkan. ${ }^{8}$

\section{B. Metodologi}

4 Syed Muhammad Naquib al-Attas, Islam Dan Sekularisme, Penerjemah Dr. Khalif Muammar, M.A., (Bandung: PIMPIN, 2010), hlm. 169.

5 Adnin Armas, Konsep Ilmu Dalam Islam, hlm.1, dalam Adian Husaini (ed), Islamic Worldview: Bahan-Bahan Kuliah Di Program Pasca Sarjana Universitas Ibn Khaldun Bogor.

6 Budi Handrianto, Ide Islamisasi Ilmu Pengetahuan, makalah kuliah pasca sarjana Universitas Ibn Khaldun Bogor, tahun 2007, hlm.1; Budi Handrianto, Islamisasi Sains: Sebuah Upaya Mengislamkan Sains Barat Modern, (Jakarta: Pustaka Al-Kautsar), hlm. 28, selanjutnya disingkat Islamisasi Sains.

${ }^{7}$ Lihat karya Wan Mohd Nor Wan Daud,The Educational Philosophy and Practice Of Syed Muhmmd Naquib al-Attas: An Expesition Of The Original Concept Of Islamization, (Kuala Lumpur: ISTAC, 1998), hlm. 237.

${ }^{8}$ Wan Mohd Nor Wan Daud, The Educational Philosophy, (Kuala Lumpur: ISTAC, 1998), hlm. 291. 
Ini adalah penelitian kepustakaan (studi literatur). Seluruh data penelitian merujuk pada literatur yang berkaitan objek penelitian, yaitu pemikiran Prof. Dr. S.M.N. al-Attas tentang konsep Islamisasi ilmu pengetahuan kontemporer. Sebagai suatu kajian terhadap pemikiran tokoh, dalam hal ini penulis mengunakan pendekatan filosofis, ${ }^{9}$ yaitu pendekatan yang menggunakan argumen-argumen, pemikiran dan logika dalam analisis data. Kemudian, karena penelitiannya terhadap pemikiran dan idenya serta pembentukan watak tokoh tersebut selama hidupnya, maka sebagai pendekatanya adalah historical approach (pendekatan sejarah).

\section{Konsep Islamisasi Ilmu Pengetahuan Kontemporer Perspektif S.M.N. al-Attas}

Sekularisasi ilmu pengetahuan di Barat menyebabkan terpisahnya tujuan pencarian ilmu pengetahuan sebagai basis terciptanya suatu masyarakat yang bermoral. Itu terjadi karena cara pandang sekuler bahwa tujuan ilmu adalah ilmu. Sedangkan menurut Islam, tujuan ilmu adalah penghambaan kepada Allah swt. dan merupakan implementasi dari prinsip tauhid. Islam tidak sependapat dengan pandangan dunia Barat yang secara bebas mengeksploitasi alam dan manusia demi ilmu pengetahuan, apalagi bilamana ilmu pengetahuan dimanfaatkan untuk memusnahkan umat manusia. Dengan demikian, pandangan dunia Barat yang sekuler tentang ilmu pengetahuan harus diganti dengan nilai-nilai pandangan Islam. Dan langkah pertama untuk itu adalah dengan membangun worldview dan epistemologi Islam.

\section{Prinsip-prinsip Worldview Dalam Islam}

Memahami pemikiran S.M.N. al-Attas berangkat dari keprihatinannya terhadap penyempitan makna istilah-istilah ilmiah Islam yang disebabkan oleh upaya westernisasi, mitologisasi, pemasukan hal-hal yang magis (gaib) dan sekularisasi, dengan proses dewesternisasi dan Islamisasi sebagai langkah awal pembangunan paradigma pemikiran Islam kontemporer. ${ }^{10}$

Bila dikaji secara historis, paradigma pemikiran S.M.N. al-Attas merupakan sebuah pemikiran yang berawal dari metafisika ke dunia

\footnotetext{
${ }^{9}$ Metode penelitian filosofis ini dilakukan dengan cara metodis umum yang berlaku bagi pemikiran filsafat. Metodologi Penelitian Filsafat (Yogyakarta: Kanisius, 1990), hlm. 63-65.

${ }^{10}$ Lihat Nur Hasan, "Kritik Islamic Werldview Syed Muhammad Naquib al-Attas Terhadap Western Worldview”, Jurnal Studi KeIslaman MARAJI' Vol. 1, No. 1, September 2014, hlm. 120.
} 
kosmologis dan bermuara pada psikologis. ${ }^{11}$ S.M.N. al-Attas membangun epistemologinya banyak mengadopsi pandangan-pandangan yang dikemukakan oleh Imam al-Ghazâlî $(1058-1111 \mathrm{M})$ terutama dalam kitab Ma'ârid yang diturunkan dari kitab Shifâ' dan Najât oleh Ibn Sînâ (980$1037 \mathrm{M}) .^{12}$

Pemikiran metafisika S.M.N. al-Attas berangkat dari paham teologi dan tradisi tasawuf. ${ }^{13}$ Dia memberikan batasan yang jelas mengenai berbagai tingkatan para salik yaitu: mubtadi', mutawassit, dan muntahî. Pada tingkat tertinggi ini si salik memasuki dunia filsafat dan metafisika. ${ }^{14}$ Oleh karena itu, menurut Professor al-Attas, epistemologi Islam, menekankan pentingnya intuisi dalam perolehan ilmu melalui proses iluminatif. Menurutnya, Intuisi ini adalah pekerjaan dari qalb (hati). ${ }^{15}$ Pada hakikatnya, pandangan alam atau Worldview lebih dari sekadar gambaran yang hanya merupakan sinopsis dan perluasan konseptual hasil-hasil dari ilmu-ilmu alam ke dalam suatu pandangan ilmiah atas dunia. ${ }^{16}$

Islam adalah agama universal. Kedudukan Islam sebagai agama menyeluruh (universal) bagi seluruh umat manusia jelas semenjak kemunculannya di dunia. ${ }^{17}$ Islam juga turut memformulasikan pandangan (views) yang bersifat fundamental secara benar mengenai hakikat Tuhan,

\footnotetext{
${ }^{11}$ Al-Rasyidin dan Nizar, Filsafat Pendidikan Islam: Pendekatan Historis, Teoritis, dan Praktis, (Jakarta: Ciputat Press, 2002), hlm. 124.

${ }^{12}$ Akan tetapi menurut Professor al-Attas, Imam al-Ghazâlî telah memodifikasi konsep para filsuf Islam tersebut dan mengafirmasi bahwa apa yang diafirmasi mereka tidak berlawan dengan agama dan sebaliknya agama meminjam dukungan teori mereka dalam hal ini. Hanya saja klaim tentang keutamaan intelek sebagai petunjuk satu-satunya untuk mengetahui sifat dasar realitas dibantahnya dalam kitab tahâfut alfalasifah yang ditulisnya. Lihat catatan kaki S.M.N. al-Attas, Prolegomena, hlm. 167.

${ }^{13}$ Tasawwuf Menjadi pintu masuk kepada kajian Professor al-Attas terhadap metafisika. Sebagaimana diketahui kajiannya terhadap tasawwuf dilakukannya dalam rentang waktu yang lama. Pemikiran Professor al-Attas terhadap tasawuf terdapat dalam karya S1, S2, dan S3-nya. Al-Attas membahas tasawuf dengan merujuk kepada ahli tasawuf terkemuka khususnya di Nusantara dan di dalam tradisi peraddaban Islam. Persoalan utama yang dibahas dalam kajiannya terhadap tasawuf adalah persoalan wujud, Tuhan, alam dan manusia. (Lihat Adnin Armas, "Wacana Metafisika al-Attas", Jurnal Pemikian dan Peradaban Islam ISLAMIA, Vol. XI, No. 2, Agustus, 2017, hlm. 29-35).

${ }^{14}$ Abdur Rahnman Haji Abdullah, Pemikiran Islam di Malaysia: Sejarah dan Aliran, (Jakarta: Gema Insani Press, 1997), hlm. 65.

${ }^{15}$ Syed Muhammad Naquib al-Attas, Prolegomena to the Metaphisics of Islam, hlm. 119.

${ }^{16}$ Lihat Lorens Bagus, Kamus Filsafat, (Jakarta: Gramedia Pustaka Utama, 2005, Cet. 6), hlm. 1178.

${ }^{17}$ Mohammad Nasrin Nasir \& Malki Ahmad Nasir, Sains Islam, hlm. 11; Lihat juga Qs. AlAnbiya': 107; Q.S. Saba': 28; Q.S. Al-A'raf: 158; Q.S. Al-Furqan: 1; Q.S. Ibrahim: 1.
} 
para Nabi dan Rasul-Nya, Kitab Suci-Nya, alam semesta, manusia, iman, ilmu, akhlak, kehidupan dunia dan akhirat, dan lain sebagainya. Islam juga di pahami sebagai al-Din yang mempunyai makna yang jelas dan terperinci. ${ }^{18}$ Pandangan alam atau worldview Islam ini begitu penting untuk diperkukuh dan didiskusikan kembali agar umat Islam ini benar-benar memahami berbagai realitas dan perkara sesuai dengan tuntunan yang benar. Pandangan ini akan memberikan landasan cara berpikir secara tepat.

\section{a. Definisi Worldview (Pandangan alam) Islam}

Worldview dapat dikatakan sebagai kepercayaan dan pikiran seseorang yang berfungsi sebagai asas atau motor bagi segala perilaku manusia. Jadi worldview adalah istilah netral yang dapat diaplikasikan ke dalam berbagai dinominasi agama, kepercayaan, atau lainnya. Sebab ia adalah faktor dominan dalam diri manusia yang menjadi penggerak dan landasan bagi aktivitas seluruh kegiatan kehidupan manusia. ${ }^{19}$ Maka konsekuensinya, setiap konsep atau teori yang muncul dari seseorang dengan worldview tertentu akan dengan sendirinya mencerminkan struktur pengetahuan. ${ }^{20}$

Worldview dalam konteks Islam merupakan proyeksi berbagai konsep seminal (seminal concept) yang berasal dari wahyu dan yang terdiri dari elemen-elemen yang mendasar yang memiliki gambaran dan karakter yang unik. Sebagai worldview yang teistik, maksudnya yaitu keyakinan bahwa Tuhan itu ada dan menciptakan alam semesta, Dia membuat manusia menjadi pusat dari penciptaan ini. Maka, dari 'konsep Tuhan' lah konsepkonsep lain berasal. Oleh sebab itu, dengan kita mengacu pada worldview Islam, masuk akal bila Professor al-Attas menempatkan konsep hakikat Tuhan di tempat pertama sebelum konsep-konsep lain. Sebab, dari konsep hakikat Tuhan ini, konsep-konsep wahyu, penciptaan, kebahagiaan (happiness/sa'adah), nilai dan moralitas, diri manusia, pengetahuan, agama, kebebasan, dan lain sebagainya akan dengan sendirinya mengikuti. ${ }^{21} \mathrm{Hal}$ ini

\footnotetext{
${ }^{18}$ Syed Muhammad al-Attas, Prolegomena to the Metaphysics of Islam, hlm. 51-96.

19 Lihat Hamid Fahmy Zarkasyi, "Islam sebagai Pandangan Hidup", dalam Tantangan Sekularisasi dan Liberalisasi di Dunia Islam, ed. Tim KB Press (Jakarta: Khairul Bayan, 2004), hlm. 4.

${ }^{20}$ Hamid Fahmy Zarkasyi, Al-Ghazali's Concept of Causality; With Reference to His Interpretations of Reality and Knowledge, terj. Burhan Ali \& Yulianingsih Riswan, Kausalitas Alam atau Tuhan? Membaca Pikiran Religio-Saintifik al-Ghazali, (Ponorogo: UNIDA Gontor Press, 2018), hlm. 14.

${ }^{21}$ Hamid Fahmy Zarkasyi, Ibid, hlm. 14-15 mengutip S.M.N. al-Attas, The Worldview of Islam, An Outline, Opening Adress”, dalam Sharifah al-Attas (ed.), Islam and the Challenge
} 
menunjukan kepada kita bahwa konsep Tuhan merupakan dasar bagi konsep-konsep lainnya.

Hamid fahmy Zarkasyi dalam artikelnya, "Worldview Sebagai Asas Epistemologi Islam”, menyebut bahwa terdapat empat orang pemikir Muslim yang sezaman yang membicarakan makna atau makna worldview Islam. Mereka adalah Maulana Maududi, Sayyid Quthub, Mohammad Atif alZayn, dan S.M.N. al-Attas, mereka menyebut kata 'worldview' Islam dengan berbagai istilah, yaitu Islami Nazhariat, al-Tashawwur al-Islami, al-Mabda' alIslami, dan Ru'yat al-Islam li al-Wujud..$^{22}$ Definisi yang akan dirujuk untuk menjelaskan dan menguraikan pengertian worldview Islam adalah seperti yang didefinisikan oleh S.M.N. al-Attas, yaitu berdasarkan uraian yang lebih cenderung kepada makna epistemologis dan metafisik. Dengan demikian, pengertian worldview Islam yang merujuk pada makna epistemologis dan metafisik adalah suatu pandangan alam mengenai realitas dan hakikat kebenaran (truth) yang nampak oleh mata hati kita dan yang menjelaskan hakikat wujud secara jelas. ${ }^{23}$

Pandangan alam Islam tentang realitas dan hakikat kebenaran (Ru'yatu al-Islam Li al-Wujud) tidak saja merujuk kewujudan yang bersifat dapat diinderi atau hissi (sensible). ${ }^{24}$ Kewujudan sesuatu itu disebut wujud karena panca-indera dapat merasakan melalui penglihatan, pendengaran, rabaan, penciuman, dan sebagainya. Siapa pun pasti percaya terhadap 'kewujudan' tersebut. Kewujudan ini merujuk kepada adanya wujud Allah SWT, malaikat, adanya pahala dan siksa, siksa dan nikmat kubur, serta surga dan neraka, dlsb. Justru, maksud ru'yat al-Islam Li al-Wujud merangkumi kewujudan yang sensible dan non-sensible. ${ }^{25}$

of Modernity, Proceeding of the Inaugural Symposium on Islam and the Challenge of Modernity: Historical and Contemporary Context, Kuala Lumpur August, 1-5, 1994, (Kuala Lumpur, ISTAC, 1996), hlm. 29.

${ }^{22}$ Lihat lebih lanjut dalam Hamid fahmy Zarkasyi, "Worldview Sebagai Asas Epistemologi Islam", hlm. 9-20 dalam Jurnal Pemikiran dan Peradaban Islam Islamia, Thn. II, No. 5, April-Juni 2005. Lihat juga Nur Hasan, "Kritik Islamic Werldview Syed Muhammad Naquib alAttas Terhadap Western Worldview”, Jurnal Studi KeIslaman MARAJI' Vol. 1, No. 1, September 2014, hlm. 115-145.

${ }^{23}$ Syed Muhammad Naquib al-Attas, Prolegomena to the Metaphysics of Islam, (Kuala Lumpur: ISTAC, 1995), hlm. 2.

${ }^{24}$ Lihat uraian yang lebih komprehensif mengenai hal ini dalam Akhmad Rofi'i Damyati, "Makna dan Hakikat Wujud Dalam Pemikiran al-Attas", Jurnal Pemikiran dan Peradaban Islam ISLAMIA, Vol. XI, No. 2, Agustus 2017, hlm.36-46.

${ }^{25}$ Mohammad Nasrin Nasir \& Malki Ahmad Nasir, Sains Islam, hlm. 15. 
Ini penting dalam melihat "fenomena" munculnya pandangan alam lain yang tentunya akan berbeda dengan pandangan alam Islam. Pemahaman dan pandangan umat Islam terhadap perkara 'kewujudan' dua alam itu penting, sebagaimana mereka melihat realias dan hakikat kebenaran. Worldview Islam tidak hanya terbatas kepada dunia fisik atau keterlibatan manusia yang baik dari aspek social, politik, budaya, dan sejarah saja, tetapi juga harus mencakup aspek akhirat (ukhrawi). Karena, aspek dunia harus bekaitan secara erat dengan akhirat, dan aspek ini harus diletakan sebagai tujuan dan landasan kita hidup di dunia sehingga dapat mengawal kepada niat dan cara pandang umat Islam serta umat manusia secara keseluruhan. ${ }^{26} \mathrm{Hal}$ ini sebagaimana yang di definisikan oleh S.M.N. al-Attas sebagai berikut,

"The worldview of Islam is not merely the mind's view of the physical world and man's historical, social, political and cultural invlvelent in it. It is not based upon philosophical speculation formulated mainly from observation of the data of sensible experience, the world of created things...Thus, what is meant bay 'worldview' according to the perspective of Islam is the vision of reality and truth that appears before our mind's eye revealing what existence is all about; for it is the world of existence in its totality that Islam is projecting. In other world, it is ru'yah al-Islam li al-Wujud." ${ }^{27}$

Secara epistemologis dan metafisik, hasil uraian dan tafsir (interpretation) atas fakta atau segala sesuatu itu menjadi suatu "identitas yang selaras" kepada worldview atau pandangan alam Islam. Sebagaimana yang telah di definisikan oleh Professor al-Attas di atas, yaitu "the vision of reality and truth that appears before our mind's eye revealing what existence is all about" atau wawasan tentang realitas dan kebenaran yang muncul sebelum pikiran kita 'mendedahkan' suatu yang wujud tersebut. Dari pendefinisian tersebut, terdapat tiga kandungan penting yang dapat dijadikan identitas framework (kerangka berfikir), yaitu worldview adalah mesin atau 'motor pengegerak' bagi perubahan sosial, dasar atau asas bagi pemahaman hakikat realitas dan asas bagi aktivitas keilmuan.

\footnotetext{
${ }^{26}$ Syed Muhammad Naquib al-Attas, Prolegomena to the Metaphysics of Islam, (Kuala Lumpur: ISTAC, 1995), hlm. 1

${ }^{27}$ Syed Muhammad Naquib al-Attas, Prolegomena to the Metaphysics of Islam, (Kuala Lumpur: ISTAC, 1995), hlm. 1; Lihat juga Adnin Armas, Westernisasi Dan Islamisasi Ilmu, Makalah Diskusi Sabtuan INSISTS pada tanggal 19 Mei 2007, hlm.8, dalam Adian Husaini (ed), Islamic Worldview: Bahan-Bahan Kuliah Di Program Pendidikan Dan Pemikiran Islam Pasca Sarjana Universitas Ibn Khaldun.
} 
b. Ciri dan Elemen Pandangan Alam Islam (Worldview) Islam

Pandangan alam (worldview) Islam sebagai sebuah sistem yang jelas dan definitive, memiliki berbagai elemen yang unik dan tersendiri, sehingga ia menjadi asas pembeda dengan pandangan alam (worldview) yang lain.

Di dalam pandangan alam (worldview) Islam ini menurut Hamid Hamid Fahmy Zarkasyi, justru pembicaraan mengenai sesuatu yang berkaitan dengan pandangan hidup, aqidah, filsafat, atau prinsip hidup adalah wsama, karena istilah-istilah ini pada dasarnya membicarakan suatu prinsip yang dasar (asas) dan menjadi bagian dari pembahasan ilmu dan metafisik, dan juga teologis. ${ }^{28}$ Akan tetapi, elemen-elemen yang menjadi asas pandangan alam Islam, sebagaimana yang dikemukakan oleh Professor alAttas adalah sifat Allah SWT, sifat wahyu yaitu al-Qur'an, sifat agama wahyu, yaitu Islam, sifat dunia, sifat manusia, siafat ilmu pengetahuan ('ilm), sifat adab, dan sifat kebahagiaan (sa'aadah/happiness). ${ }^{29}$ Secara ringkas, untuk memperlihatkan secara jelas perbedaan yang kentara antara worldview Islam dengan Barat, kita dapat memerhatikan tabel yang diambil dari Hamid Fahmy Zarkasyi di bawah ini.

\begin{tabular}{|c|c|c|c|}
\hline Aspek I & Perbedaan & Worldview Islam & Worldview Barat \\
\hline 1. & Prinsip & Tauhid & Dikotomis. \\
\hline 2. & Asas: & $\begin{array}{l}\text { Wahyu, Hadits, akal, } \\
\text { Pengalaman, dan intuisi }\end{array}$ & Rasio, spekulasi filosofis \\
\hline 3. & Sifat: & Autentisitas dan finalitas. & $\begin{array}{l}\text { Rasional, terbuka dan selalu } \\
\text { berubah. }\end{array}$ \\
\hline $\begin{array}{l}4 . \\
\text { realitas: }\end{array}$ & Makna & $\begin{array}{l}\text { Berdasarkan kajian } \\
\text { metafisik. }\end{array}$ & $\begin{array}{l}\text { Pandangan sosial, budaya, } \\
\text { dan empiris. }\end{array}$ \\
\hline $\begin{array}{l}5 . \\
\text { kajian: }\end{array}$ & Objek & $\begin{array}{l}\text { Sesuatu yang tampak jelas } \\
\text { dan tidak tampak. }\end{array}$ & Tata nilai di masyarakat \\
\hline
\end{tabular}

\section{Landasan Epistemologi Islam}

Kritik terhadap filsafat pengetahuan dan sains Barat diantaranya telah dilontarkan oleh S.M.N. al-Attas, seorang Intelektual Muslim kontemporer

\footnotetext{
${ }^{28}$ Hamid fahmy Zarkasyi, "Worldview Sebagai Asas Epistemologi Islam", hlm. 12.

${ }^{29}$ Mohammad Nasrin Nasir \& Malki Ahmad Nasir, Sains Islam, hlm. 20 mengutip al-Attas \& Wan Daud, 2007, hlm. 9-25 dan al-Attas, 1996.
} 
yang memiliki perhatian khusus terhadap sekularisme dan liberalisme. ${ }^{30}$ Professor al-Attas melihat permasalahan yang paling serius dan destruktif (merusak) di zaman ini datang dari kebudayaan Barat yaitu kerusakan ilmu akibat disebarkannya ilmu-ilmu yang tampak seperti ilmu sebenar, tetapi sesungguhnya menebarkan confuse (kebingungan) serta kekeliruan dan sikap skeptis pada diri manusia. ${ }^{31}$

Dalam pandangan S.M.N. al-Attas, kebingungan intelektual muncul sebagai hasil dari larangan dan perubahan penggunaan kata-kata kunci yang memproyeksikan pandangan alam Islam (Islamic worldview) yang berasal dari wahyu. Kebingungan intelektual menjelma menjadi kerusakan kebudayaan dan moral yang merupakan gejala kemerosotan ilmu agama, keimanan, serta nilai-nilai. ${ }^{32}$

\section{a. Pengertian Epistemologi}

Manusia mempunyai peranan yang signifikan dalam membuat pertimbangan, dan keputusan, serta tindakan pada kehidupan ilmiah. Ilmu yang dikaji secara mendalam dan sistematis, kriteria-kriteria dalam perolehannya dengan keterbatasan-keterbatasannya serta menjustifikasi ilmu tersebut, dikenal dengan nama "Epistemologi" ${ }^{33}$ Epistemologi berasal dari bahasa Yunani episteme yang berarti 'pengetahuan' (knowledge) dan logos yang berarti 'ilmu'. 34

Sepanjang sejarah manusia, persoalan epistemologi merupakan hal yang sangat kentara dalam melihat, memahami dan membuat penilaian terhadap sesuatu. ${ }^{35}$ Epistemologi membahas secara mendalam segala sesuatu mengenai proses yang terlihat dalam usaha manusia untuk

\footnotetext{
30 Dinar Dewi Kania, "Pemikiran Epistemologi al-Attas", Jurnal Pemikian dan Peradaban Islam ISLAMIA, Vol. XI, No. 2, Agustus, 2017, hlm. 16.

${ }^{31}$ Syed Muhammad Naquib al-Attas, Islam the Concept of Religion and the Foundation of Ethics and Morality, (Kuala Lumpur: IBFIM, 2013), hlm. 43-44.

32 Syed Muhammad Naquib al-Attas, Prolegomena to the Metaphysics of Islam, (Kuala Lumpur: ISTAC, 2005), hlm. 15.

33 Vincent E. Hendricks, Mainstream and Formal Epistemologi, (Cambridge: Cambridge University Press, 2006), hlm. 1.

${ }^{34}$ Jonathan Ree (ed.), The Concise Encyclopedia of Western Philosophy, $3^{\text {rd }}$ Edition, (New York: Routledge, 2005), hlm. 112-113.

${ }^{35}$ Mohammad Nasrin Nasir \& Malki Ahmad Nasir, Sains Islam: Konsepsi Baharu Hubungan Sains dengan Agama, (Negeri Sembilan Malaysia: USIM, 2016), hlm. 28. Selanjutnya di singkat Sains Islam.
} 
memeroleh ilmu. ${ }^{36}$ Ilmu merupakan pengetahuan yang di dapat melalui metode keilmuan sehingga metode inilah yang membedakan ilmu dengan buah pemikiran lainnya. ${ }^{37}$ Sedangkan menurut Richard Fumerton, pertannyaan-pertanyaan tentang epistemologi mencakup konsep ilmu, bukti, alasan untuk memercayai, serta konsep-konsep lainnya yang hanya dapat dipahami melalui satu atau beberapa hal tersebut diatas. ${ }^{38}$ Epistemologi bertujuan untuk menganalisa proses bagaimana mendapatkan ilmu. Oleh sebab itu, pertama-tama harus diketahui di mana proses tersebut bermula dan kapan harus berakhir. ${ }^{39}$

Menurut Mohammad Nasrin Nasir \& Malki Ahmad Nasir, justru yang di maksud dengan epistemologi adalah ilmu atau kajian tentang pengetahuan yang perbincangannya merangkumi sesuatu yang berkaitan dengan asal, sifat, karakter dan jenis ilmu atau pengetahuan. Epistemologi merupakan salah satu cabang filsafat, termasuk yang sering diperdebatkan dan di bahas dalam bidang filsafat ilmu (philosophy of science) khususnya, yaitu mengenai apa itu pengetahuan, bagaimana ciri-cirinya, jenisnya, serta hubungannya dengan nilai kebenaran dan nilai keyakinan. ${ }^{40}$

Oleh karena itu, epistemologi berkait erat dengan pertanyaanpertanyaan seperti, apakah itu ilmu atau pengetahuan atau asal-usulnya? Bagaimana dan apakah kriteria atau sifat ilmu atau pengetahuan? Bagaimakah ilmu dapat dikuasai atau cakupannya? Bagaimana manusia memeroleh ilmu atau pengetahuan? Atau berapa luas subjek atau entitas yang mungkin dapat diketahui dari pengetahuan tersebut?

\section{b. Epistemologi dan Prinsipnya Dalam Bingkai Islam}

Pembahasan tentang nilai, struktur, batasan dan sumber ilmu perngetahuan berarti juga mempertanyakan perkara-perkara lain. Walaupun pertanyaanpertanyaan berikut ini sudah "bisaa" di perbincangkan dalam wilayah yang di kenal dengan kajian aksiologi dan ontologi, teapi tetap saja menjadi isu yang sangat penting dalam 'mengukuhkan' dasar epistemologi yang benar

\footnotetext{
${ }^{36}$ Ahmad Tafsir, Filsafat Ilmu: Mengurai Ontologi, Epistemologi, dan Aksiologi Pengetahuan, (Bandung: Remaja Rosda Karya, 2013, cet. IIV), hlm. 69.

${ }^{37}$ Jujun Suriasumantri, Ilmu dalam Perspektif, (Jakarta: Yayasan Obor Indonesia, 2009, cet. 17), hlm. 9. Jujun Suriasumantri, Filsafat Ilmu: Sebuah Pengantar Populer, (Jakarta: Pustaka Sinar Harapan, 2010, cet. 22), hlm. 101-141.

${ }^{38}$ Richard Fumerton, Epistemology, (Oxford: Blackwell Publishing, 2005), hlm. 1.

${ }^{39}$ Alparslan Acikgence, Scientific Thought and Its Burden: An Essay in the History and Philosophy of Science, (Istambul: Fatih University Yiyinlari, 2000), hlm. 26.

${ }^{40}$ Mohammad Nasrin Nasir \& Malki Ahmad Nasir, Sains Islam, hlm. 29.
} 
menurut perspektif Islam. Iman An-Nasafi, dalam karyanya yang berjudul al'Aqa'id an-Nasafiyah, sebuah kitab akidah yang menjadi panduan dan pengangan bagi kalangan ahlu al-sunnah wa al-jama'ah, menjawab pertanyaan bagaimanakah ilmu pengetahuan dapat dicapai oleh manusia? Apakah yang di tangkapnya itu realitas yang terbatas atau justru sebaliknya? Dan bagaimana mendefinisikan realitas itu? Dan jika yang ditangkapnya adalah realitas yang tak terbatas, dengan cara apa untuk memerolehnya? Lantas selanjutnya, apakah semua ilmu pengetahuan yang telah diperoleh mempunyai nilai (value) bersifat pasti atau sebaliknya?

Maka, untuk menjawab serta merumuskan prinsip-prinsip epistemologi dalam Islam, Imam An-Nasafi, melalui karyanya tersebut menyatakan, "Haqai'q al-Asyya' tsabitah wa al-Ilmu biha mutahaqqiq khilafan li al-Sufasthai'yya" ${ }^{41}$ Maksudnya, hakikat atau intisari segala sesuatu itu adalah tetap (tsabitah) sehingga dapat di tangkap, di pahami, dan tidak berubah karena sesuatu yang berubah-ubah itu hanya sifatnya saja, 'arad, lawahiq atau lawazin, sehingga segalanya dapat di ketahui dan dikenali dengan jelas dan terang.

Walaupun demikian, masalah terbatasnya manusia sangat berkait dengan kondisi intrinsik dan ekstrinsik. ${ }^{42} \mathrm{Hal}$ ini bagaimanapun juga tidak sampai berakibat menggugurkan nilai kebenaran dan keabsahan pengetauan itu sendiri, sebab, kodisi normal manusia yang sempurna dan sehat fisik tidaklah menjadi 'ukuran' untuk meraih pengenalan tersebut. Kondisi yang normal ini sebenarnya mempunyai potensi yang sama dengan yang cacat dan tidak sehat secara jasmani, karena perkara yang paling adalah kondisi yang sehat secara mental, roh, termasuk akal dan hatinya. ${ }^{43}$

Hakikat atau intisari sesuatu adalah tetap (tsabit), dan ilmu pengetahuan mengenai hakikat dapat dikenali dan ditangkap, sengan syarat kondisi kemampuan manusia dalam keadaan normal, yaitu sehat secara rohani.

Islam memberikan penekanan mengenai pentingnya ilmu dalam usaha memenuhi keperluan spiritual dan meraih kebahagiaan yang hakiki. Sebab, melalui ilmu, makna kebahagiaan dapat dipahami secara benar. Tidak hanya dihayati sekedar konsep dan tujuan sementara, ataupun dipahami sebagai sesuatu yang bersifat kesenangan material atau fisik yang

${ }^{41}$ Syed Muhammad Naquib al-Attas, The Oldest Known Malay Manuscript: A $16^{\text {th }}$ Century Malay Translation of the 'Aqa'id of al-Nasafi, (Kuala Lumpur: University of Malaya Publications Department, 1988), hlm. 101.

${ }^{42}$ Mohammad Nasrin Nasir \& Malki Ahmad Nasir, Sains Islam, hlm. 30,

${ }^{43}$ Syamsuddin Arif, Orientalis dan Dioabolisme Pemikiran, (Jakarta: GIP, 2005), hlm. 28. 
tidak kekal ataupun yang berkaitan dengan keadaan kesenangan mentatl dan pikiran.

Justru, pemberitaan mengenai berbagai 'sesuatu' tersebut adalah mesti benar-mutlak, seperti tentang adanya hakikat Sang Pencipta dan makhluk, alam, tujuan hidup, wahyu, adanya balasan perbuatan, qadha dan qadar, serta surga dan neraka. Ataupun mengenai bagaimana mengenali mana yang haq dengan mana yang bathil itu dapat di usahakan secara menyeluruh, sehingga ilmu yang benar ini dapat menyelesaikan berbagai permasalahan yang terjadi dalam kalangan masyarakat.

Tidak berlebihan jika Islam disebut dengan agama yang berdasar ilmu. Professor al-Attas menyatakan,

"beginning the creed on define statements about knowledge is is most significant, for Islam is a religion based upon knowledge, and a denial of the possibility and objectivity of knowledge would involve the destruction of the fundamental basis upon which not yet only the religion, but all the sciences are rooted." 44

Tidak diragukan, jika wacana ilmu ('ilm) merupakan sebagian wacana yang sangat penting (urgent) dalam worldview Islam. Wacana ilmu juga menjadi wacana yang penting ketika lmu menujukan kebenaran (alhaqq), dan pada saat yang sama juga membicarakan konsep kebenaran. Hal ini berbeda dengan worldview Barat dan pandangan lain, yang menyatakan bahwa kebeanran itu merupakan suatu kesesuaian dalil dengan fakta atau realitas.

Oleh karena itu, dalam memandang kebenaran Islam tidak sekedar memandang fakta, tetapi juga harus sesuai dengan fitrah penciptaan yang merujuk tempat yang yang sesuai serta benar dari segala sesuatu. Memang benar Islam juga menggunakan cara pandang yang bersumberkan alat inderawi dan akal, tetapi kedua cara pandang dan sumber itu dalam Islam tiada mencukupi. Kebenaran (al-Haqq) dalam Islam tidaklah hanya berupa adanya kesesuaian sesuatu dengan fakta atau realitas yang berifat waqi'iyyah, tetapi kebenaran tersebut sesuai dengan fitrah dan bersifat haqiqiyyah. Apaapa yang disebut dalam al-Qur'an dan al-Sunnah adalah benar, maka itulah

\footnotetext{
${ }^{44}$ Syed Muhammad Naquib al-Attas, The Oldest Known Malay Manuscript: A $16^{\text {th }}$ Century Malay Translation of the 'Aqa'id of al-Nasafi, (Kuala Lumpur: University of Malaya Publications Department, 1988), hlm. 47. selanjutnya disingkat The Oldest Known Malay Manuscript.
} 
al-Haqq (kebenaran), dan apa-apa yang dikatakan batil, maka justru itulah yang batil (al-Bathil). ${ }^{45}$

Dalam epistemologi Islam juga terdapat sebagai cara untuk dapat mengetahui dan memahami fenomena alam. Hal ini berbeda dengan opistemologi golongan Sophists yang hidup sebelum zaman Socrates, Plato dan Aristoteles, yang menyatakan bahwa manusia tidak bisa mengetahui tentang suatu perkara. Golongan ini disebut dalam karya-karya yang membahas tentang akidah ('aqa'id) sebagai golongan "al-Sufasha'iyyah", sebagaimana yang dijelaskan oleh S.M.N. al-Attas berikut ini,

"In Islam the sophistai became known as the sufasta, and their various schools the sufasta'iyyah. Al-Baghdadi (d. 103/78) was one of the earliest authorities to write about them and to identify them into three groups. Al-Nasafi reffered to them in the Aqa'id, and his commentator, al-Taftazani, mentioined the names of the three groups and gave a resume of their beliefs in his commentary. Al-Raniri, deriving perhaps from the al-Taftazani's commentary, also mentioned the three groups in question, giving a brief exposition of their beliefs in his Tibyan." 46

Kemudian berkembang dan terwujudlah golongan pseudo-science ini kedalam berbagai bentuk dan rupa, serta dengan kecenderungan yang khas dari masing-masing. Seperti golongan the al-inadiyyah, al-indiyyah, dan al-la adriyyah. Mengenai hal ini, S.M.N. al-Attas menjelaskan secara detail tentang rupa dan wujud golongan ini. Beliau menulis,

"...The expression la adri means 'I do not know', and the la adriyyah are people who say that they do not know whether or nor a thing has real existence. They are in doubt about the real existence of thing, and are in doubt even of their own doubt. They are therefore pwople who deny the possibility of knowledge, and are properly called agnostics. As to the second appellation, the word 'indi' means 'according to me', or 'to my opinion'; and the 'indiyyah' are people who say that there is no objective truth in knowledge; all knowledge, they say is subjective, and the truth about anything is only one's opinion of it. In this sense they are epistemological Subjectivists. Finally, in the case of the third goup called the 'indiyyah, which means 'the obstinate', they refer to people who deny the realities of things and maintain that what we call 'things' are mere fancies and figments of the imagination. In a sense the Obstinate are closer in ideas to the Subjectivists than the Agnostics, although in fact all the three groups have in common the denial of objective knowledge. The beliefs of these three groups, which from the basic elements of the position of the Sophists, are in direct opposition to Islam which, as I said, affirms the objectivity of knowledge and the existence of realities. It is obvious

\footnotetext{
${ }^{45}$ Lihat misalnya, Q.S. al- Isra (17): 81.

${ }^{46}$ Syed Muhammad Naquib al-Attas, The Oldest Known Malay Manuscript. Hlm. 24-25.
} 
that such beliefs represent fundamental deviations from religion and from science and can bring about destructive concequences in human society. It is also significant that al-Raniri in his debates and polemics against the heretics identified the pseudo-Sufis in the Malay world with the Sophists, so that the relevance of the Aqa'id (III), to the religious and intellectual atmosphere of the time on this question is quite indisputable." 47

Cara berpikir model epistemologi kaum Sophist ini dalam konteks Islam, sudah jelas pasti akan ditolak. Namun menerima cara berpikir para filosof yang hidup sesudahnya dilihat dari pandangan bahwa manusia dapat tahu tentang sesuatu dapat diterima. Tetapi, epistemologi Islam tidak hanya 'mendiskusikan' dapat tahunya saja yang juga tebatas pada dua sumber tersebut, yaitu panca-indera dan akal manusia. Bahkan lebih dari itu, Islam telah menyempurnakan pengetahuan manusia ini melalui sumber ilmu lagi, yaitu wahyu. Istilah teknis wahyu ini disebut dengan istilah "khabar shadiq" atau berita yang benar. ${ }^{48}$

Pandangan yang lebih gamblang tentang Islam sebagai agama yang berlandaskan pada wahyu dikemukakan oleh S.M.N. al-Attas. Menurutnya, para sarjana Barat memang tidak menemukan lagi cara yang tepat untuk mendefinisikan agama kecuali dalam pengertian historisitas disebabkan fakta yang mereka temukan dalam agama Kristen Barat. Meskipun mengklaim sebagai agama yang berlandaskan pada wahyu, banyak doktrin dalam agama Kristen Barat yang menurut sumber-sumber awal Kristen sendiri tidak diilhami oleh Tuhan, sebut saja misalnya dotrin Trinitas, penebusan, inkarnasi, serta segala perincian dogma lain yang berkaitan dengannya. Maka dari itu mereka cenderung memahami bahwa agama adalah bagian dari kebudayaan dan tradisi, atau sekedar sebagai produk budaya (Muntaj al-Tsaqafi), ${ }^{49}$ yang tercipta dalam sejarah, berevolusi dalam

\footnotetext{
${ }^{47}$ Syed Muhammad Naquib al-Attas, Ibid, hlm. 48-49.

${ }^{48}$ Untuk Penjelasan yang lebih mendalam Lihat karya Imam Muhammad ibn 'Ali ibn Muhamad as-Syaukani (w. 1255 H), Irsyad al-Fuhul Ild Tahqiq al-Haqqim 'Ilmi al-Ushul, (Beirut: Dar al-Kotob al-'Ilmiyyah, 1994), hlm. 71-72.

${ }^{49}$ Lihat misalnya Karya Clifford Geertz, The Implementation of Cultures: Selected Essays, penerjemah F. Budi Hardiman, (Yoyakarta: Kanisius, cet. 9, 2003), bandingkan dengan Edi Mulyono, M. Ag., Belajar Hermeneutika, (Yogyakarta: IRCIsoD, 2012, cet. I), hlm. 225; M. Yusron, dkk., Studi Kitab Tafsir Kontemporer, ((Yogyakarta: TH-Press, 2006); Nasr Hamid Abu Zayd, Mafhum al-Nash: Dirasah fi 'Ulum al-Qur'an, (Beirut: al-Markaz al-Tsaqafiy al'Araby, 1994), hlm. 9
} 
sejarah dan akan selalu mengalami perubahan dan "perkembangan" zaman. $^{50}$

Kerancuan dari status agama Kristen sebagai agama wahyu juga terlihat dalam hukum yang diadopsinya. Adalah fakta bahwa agama Kristen tidak memiliki aturan hukum yang diwahyukan (syari'ah) yang terungkap dalam ajaran, perkataan, dan contoh pebuatan (yaitu sunnah) Nabi 'Isa as., sehingga ini menjadi petunjuk penting bahwa agama kristen bukalah bukanlah agama wahyu, melainkan agama yang dibentuk oleh manusia dalam sejarah. Maka dari itu agama Kristen secara berangsur-angsur mengembangkan sistem ritualnya dengan mengambil dan mnyerap kebudayaan dan radisi lain, di samping membuat sistem ritualnya sendiri. Secara bertahap Professor al-Attas mulai menjelaskan prinsip-prinsip agamanya seperti misalnya yang dilakukan di Nicea, Konstantinopel, dan Chalcedon. Karena tidak memiliki hukum yang diwahyukan, maka agama Kristen mengambil dan menyerap hukum-hukum (laws) Romawi. Dan karena tidak adanya worldview yang mantap yang disajikan wahyunya, maka agama Kristen harus "meminjam" worldview Yunani-Romawi dan darinya mereka membangun sistem teologi dan metafisikanya. ${ }^{51}$

S.M.N. al-Attas menegaskan, bahwa hanya Islam yang layak menyandang predikat sebagai wahyu. Sebab al-Qur'an telah menyatakan, demikian juga sejarah telah membuktikan, bahwa Islam telah lengkap dan sempuerna untuk umat manusia sejak awal mulanya. Nama Islam dan Muslim diberikan oleh Allah SWT melalui wahyu juga dari sejak awal mulanya. Wahyu itu sendiri - yang sudah diturunkan melalui para Nabi sebelumnya - disempurnakan dalam masakehidupan Nabi Muhammad saw, yang beliau saw tafsirkan dalam kehidupannya dan hokum sacral yang diajarkannya melalui perkataan dan contoh perbuatan (sunnah). Zaman dimana Nabi Muhammad saw hidup salam sejarah menjadi patokan bagi zaman kemudian, karena kebenaran dan nilai-nilai yang menuntunnya, semuanya telah ada pada masa itu.

Professor al-Attas juga menegaskan bahwa tradisi intelektual, agama dan budaya Islam tidak memiliki karakteristik yang suatu zaman dicirikan dengan menangnya sebuah pemikiran berdasarkan pada materialisme atau idealisme, dengan beragam posisi seperti empirisme, rasionalisme, positivism, kritisisme, dan lain sebagainya. Ciri-ciri periode sejarah dalam Islam juga tidak mengenal zaman klasik, pertengahan, modern dan sekarang

\footnotetext{
${ }^{50}$ Syed Muhammad Naquib al-Attas, Islam and Secularism, hlm. 26-27.

${ }^{51}$ Syed Muhammad Naquib al-Attas, Ibid, hlm. 28-29.
} 
berubah lagi kepada pasca-modern; atau juga periode renaissance (kelahiran kembali) dan enlighteniment (pencerahan). Paradigma tersebut berubahubah karena bersumber dari unsur-unsur filosofis dan budaya, dan sistem pemikirannya serta sistem nilainya bukan semata-mata berasal dari unsurunsur budaya dan filosofis yang dibantu sains, tetapi sumber aslinya adalah wahyu yang didukung oleh akal dan intuisi. ${ }^{52}$

Jadi, tegas S.M.N. al-Attas, Islam telah "dewasa” ketika muncul dalam pentas sejarah dunia. Islam tidak memerlukan proses 'pertumbuhan' kepada kedewasaan. Dengan kata lain, Islam tidak memerlukan progresivitas, perkembangan dan perubahan dalam hal-hal yang sudah sangat jelas dan final. Apa yang disebut 'perkembangan' dalam tradisi agaam budaya tidak dapat diaplikasikan ke dalam Islam, karena asumsi dan penjelasan yang memang harus terjadi dalam generasi orang-orang beriman yang berbeda Negara, dan merujuk kepada sumber yang tidak berubah. ${ }^{53}$

Objek ilmu dalam epistemologi Islam tidak semata-mata menjangkau realitas fisik, namun ia juga mengakui status ontologis dari halhal metafisik sebagai hal yang mungkin diketahui oleh manusia. Sumbersumber ilmu dalam epistemologi Islam tersiri dari (1) wahyu, berupa alQur'an dan al-Sunnah, (2) 'aql (akal) dan qalb (kalbu/hati), dan (3) pancaindera. Sedangkan proses memeroleh ilmu dalam Islam terkait erat dengan peran jiwa manusia dan diperoleh melalui beberapa sumber, yaitu: persepsi indera, akal sehat (ta'aqqul), dan institusi serta berita yang benar (khabar shadiq). Dalam epistemologi Islam, wahyu Allah SWT yang terdapat dalam al-Quran dan al-Sunnah merupakan sumber ilmu tertinggi sehingga scientific value (nilai ilmiah) dari wahyu tersebut di letakan pada tempat yang mestinya dan tidak boleh "di ceraikan" dari sains atau ilmu. ${ }^{54}$

\section{Tantangan Filsafat Ilmu Sekular}

Ketika berbincang soal western worldview, Professor al-Attas menunjuk sekularisme sebagai salah satu ideologi kelahiran Barat. ${ }^{55}$ Ideologi ini

\footnotetext{
${ }^{52}$ Syed Muhammad Naquib al-Attas, Prolegomena to the Metaphysics of Islam, hlm. 3-4.

${ }^{53} \mathrm{Ibid}, \mathrm{hlm}$. 3-4.

${ }^{54}$ Dinar dewi Kania, Objek Ilmu dan Sumber-Sumber Ilmu, hlm. 110.

${ }^{55}$ Perkataan sekular yang berasal dari bahasa Latin saeculum, mengandung suatu makna yang ditandai dengan dua pengertian yaitu waktu atau ruang. Sekular dalam pengertian waktu merujuk kepada "sekarang" atau "kini”, sedangkan dalam pengertian ruang merujuk kepada "dunia" atau "duniawi". Jadi saeculum bermakna "zaman kini” atau "masa kini”, dan zaman kini atau masa kini merujuk kepada peristiwa di dunia ini, dan itu juga berarti "peristiwa-peristiwa masa kini”. (lihat S.M.N. al-Attas, Islam dan Sekularisme, hlm. 18). Lihat
} 
memiliki peran yang sangat besar terhadap perubahan orientasi worldview dunia modern dewasa ini. ${ }^{56}$

Menurut Adian Husaini, diskursus mengenai filsafat ilmu dalam Islam akan bermanfaat jika pemahaman tentang kedudukan, tujuan, dan sifat ilmu dalam Islam itu diterima terlebih dahulu sebelumnya. ${ }^{57}$ Filsafat ilmu Barat yang sekular yang bertumpu pada akal semata dan menolak wahyu sebagai sumber ilmu telah membawa bencana besar bagi umat manusia. Filsafat ilmu sekular inilah yang selanjutnya memicu kekacauan besar dalam dunia keilmuan dan kemanusiaan dewasa ini. Dalam hal ini, S.M.N. al-Attas menyatakan,

"I venture to maintain that the greatest challenge that has sureptitiously arisen in our age is the challenge of knowledge, indeed, not as against ignorance; but knowledge as conceived and disseminated throughout the world by Western civilazation." ${ }^{58}$

Ilmu pengetahuan yang disebarkan Barat itu, menurut S.M.N. alAttas, pada hakikatnya telah menjadi problematic karena telah kehilangan tujuan yang benar; dan lebih menimbulkan kekacauan (chaos) dalam kehidupan manusia, ketimbang membawa perdamaian dan keadilan. Ilmu pengetahuan atau knowledge yang seolah-olah nyata benar, padahal memproduksi kekacauan dan skeptisisme (confusion and scepticism). Bahkan ilmu yang untuk pertama kalinya dalam sejarah telah membawa kepada kekacauan dalam "the Three Kingdom of Nature", yaitu dunia binatang, tumbuhan, dan mineral. Menurut S.M.N. al-Attas, bagi Barat, kebenaran fundamental dari agama, dipandang sekedar teoritis. Kebenaran absolut dinegasikan dan nilai-nilai relatif diterima. Tidak ada satu kepastian. Konsekuensinya, adalah penegasian Tuhan dan akhirat serta menempatkan manusia sebagai satu-satunya pihak yang berhak mengatur bumi. Manusia pun akhirnya dituhankan dan Tuhan pun dimanusiakan (man is deified and

juga, Adian Husaini, Mengapa Barat Menjadi Sekuler-Liberal?, (Ponorogo: CIOS UNIDA, 2007, Cet. I).

56 Lihat Nur Hassan, "Kritik Islamisc Worldview Syed Muhamad Naquib al-Attas Terhadap Western Worldview”, Jurnal Studi KeIslaman Maraji', vol. 1, No. 1, September 2014, hlm. 124.

57 Adian Husaini, et. al., Filsafat Ilmu Perspektif Barat dan Islam, (Jakarta: Gema Insani, 2013), hlm. 38.

58 Syed Muhammad Naquib al-Attas, Islam, Secularism, And the Philosophy Of The future, (London \& New york: Mansell Publishing Limited, 1981, Cet. 1), hlm.127. 
Deity humanised). ${ }^{59}$ Hal itu karena ilmu yang dipahami dan disebarluaskan ke seluruh dunia oleh peradaban Barat; Hakikat ilmu telah menjadi bermasalah karena ia telah kehilangan tujuan hakikinya akibat dari pemahaman yang tidak adil. S.M.N. al-Attas mencatat,

"Ilmu yang seharusnya menciptakan keadilan dan perdamaian, justru membawa kekacauan dalam hidup manusia; ilmu yang terkesan nyata, namun justru menghasilkan kekeliruan dan skeptisisme, yang mengangkat keraguan dan dugaan ke derajat 'ilmiah' dalam hal metodologi serta menganggap keraguan (Doubt) sebagai sarana epistemologis yang paling tepat untuk mencapai kebenaran; ilmu yang untuk pertama kalinya dalam sejarah, telah membawa kekacauan pada tiga kerajaan alam: hewan, tanaman dan bahan galian (mineral). ${ }^{{ }^{60}}$

Kritik-kritik S.M.N. al-Attas terhadap karakteristik keilmuan Barat modern, misalnya, juga disampaikan saat konferensi Internasional para filosof pada Januari 2000, di University of Hawaii. Konferensi ini diikuti oleh sekitar 160 cendikiawan dari 30 negara dan berlangsung selama dua minggu. Tema yang dibahas adalah "Technology and Cultural Values on the Edge of Third Millenium”. Dalam editorialnya terhadap buku kompilasi hasil konferensi itu, tiga ilmuwan terkenal, yakni Peter D. Hershock, Marietta Stepaniants, dan Roger T. Ames, mencatat bahwa paparan S.M.N. al-Attas yang menyorot kesesuaian dan ketidaksesuaian antara tradisi Barat dalam sains dan teknologi dengan sistem epistemologi dan metafisika Islam, merupakan paparan yang artikulatif, cermat, dan sistematis tentang basis revisi Islami terhadap tujuan dan premis-premis moral dalam sains dan teknologi. Dikatakan,

"In 'Islam and the chellenge of Modernity: Divergence of Worldviews', Syed Muhammad Naquib al-Attas specifically addresses the consonances and disconsonances between Western tradition of technology and science and the epistemological and metaphysical sistem of Islam. In a comprehensive overview of Islamic thought as it bears on the conference theme of technology and human values, al-Attas petitions for he determines that science and technology must be evaluated in terms of their moral valence and the extend to which their core practices and conceptual resources are (or are not) compatible with Islamic perspective on the meaning of change, devepment, and progress. His essays is an

59 Jennifer M. Webb (ed.), Powerful Ideas: Perspectif on the Good Society, (Victoria, The Cranlana Program, 2002), vol 2, hlm. 231-140.

${ }^{60}$ Syed Muhammad Naquib al-Attas, Islam Dan Sekularisme, (Bandung: PIMPIN, 2010, Cet. 2), Penerjemah Dr. Khalif Muammar, M.A. hlm. 169. 
articulate and meticulously sistematic exposition of the groundwork for a truly Islamic evision of the aims and moral premises of science and technology." 61

Ketika S.M.N. al-Attas menyampaikan makalah berjudul "Islam and the Challenge of Modernity: Divergence of Worldviews", S.M.N. al-Attas menguraikan konsep-konsep pokok dalam epistemologi dan metafisika Islam, seperti konsep "religion" dalam Islam (ad-Din), yang sember tertingginya diambil dari al-Qur'an. Al-Attas juga menguraikan tentang konsep "the truth" yang tidak mengenal dikotomi "subjektif" dan "objektif", sebagaimana dalam tradisi filsafat Yunani. Beliau juga mengkritik konsep desakralisasi alam dengan unsur Ketuhanan. Ia menekankan bahwa alam bukanlah entitas Ketuhanan, tetapi merupakan bentuk yang memanifestasikan Ketuhanan (nature in itself is not a Divine entity but a symbolic form that manifests the Divine). Agama menentang desakralisasi, jika desakralisasi diartikan sebagai pembuangan semua makna spiritual dalam pandangan terhadap alam, atau jika desakralisasi diartikan sebagai pembatasan terhadap metode pemahaman manusia terhadap metode ilmiah (scientific method) yang diajukan oleh filsafat dan sains sekular. Mengenai konsep Tuhan, S.M.N. al-Attas menggarisbawahi:

"God is not a myth, an image, a symbol, thsat keeps changing with the times. He is reality itself. Belief has cognitive content, and one of the main points of divergence between true religion and sekular philosophy and science is the way in which the sources and methods of knowledge are understood."

Dalam uraiannya ini, S.M.N. al-Attas banyak menjelaskan berbagai perbedaan fundamental antara konsep sekular Barat dan Islam dalam berbagai persoalan. Dalam soal konsep kebahagiaan (happiness), misalnya, S.M.N. al-Attas menjelaskan sikap seorang Muslim yang menolak konsep Aristotelian tentang kebahagiaan yang hanya menyentuh aspek duniawi (profane), dan sampai sekarang diikuti oleh konsep modern. Ia menegaskan tentang pandangan (worldview) Islam yang tidak memisahkan aspek duniawi dan aspek ukhrawi. Konsepsi modern mengenai kebahagiaand menurut S.M.N. al-Attas, esensinya sama dengan konsepsi manusia di masa lalu, yaitu di era paganisme. Ia menulis,

\footnotetext{
${ }^{61}$ Adian Husaini, Filsafat Ilmu, hlm. 39 mengutip dari karya Peter D. Hershock, Marietta Stepaniants, dan Roger T. Ames (ed.), "Technology and Cultural Values on the Edge of the Third Millennium”, (Honolulu: University of Hawaii Press, 2003).
} 
"We do not agree with the Aristotelian position that virtue and happiness relate only to this world... As for the modern conception of happiness, it is not different in essence from the ones known and practiced in ancient times by pagan societies."

Sedangkan konsep kebahagiaan dalam Islam atau sa'adah, akan dialami dan disadari oleh orang-orang yang benar-benar tunduk dan patuh kepada Allah SWT dan mengikuti bimbingan-Nya. Puncak kebaikan dalam hidup adalah cinta kepada Allah. ${ }^{62}$ S.M.N. al-Attas mendefinisikan kebahagiaan (sa'adah/happiness) Secara khusus sebagai berikut,

"Kesejahteraan" dan "kebahagiaan" itu bukan dianya merujuk kepada sifat badani dan jasmani insan, bukan kepada diri hayawani sifat basyari; dan bukan pula dia suatu keadaan akal-fikri insan yang hanya dapat dinikmati dalam alam fikiran dan nazar-akali belaka. Kesejahteraan dan kebahagiaan itu merujuk kepada keyakinan diri akan Hakikat Terakhir yang Mutlak yang dicari-cari itu yakni: keadaan diri yang yakin akan Hak Ta'ala-dan penuaian amalan yang dikerjakan oleh diri itu berdasarkan keyakinan itu dan menuruti titah batinnya."

Kritik-kritik terhadap sains Barat sebagai pembawa bencana bagi umat manusia juga banyak banyak dilakukan oleh ilmuwan lain. Salah satu yang cukup vocal dalam menyuarakan hal ini adalah Seyyed Hossein Nasr, yang menulis,

"Today more and more people are becoming aware that the applications of modern science, a science witch until a few decades ago was completely Western and which has now spread to other continents, have caused directly or indirectly unprecedented environmental disasters, bringing about the real possibility of the total collapse of the natural order." 64

Pemaparan S.M.N. al-Attas tentang konsep filsafat ilmu dan metafisika Islam serta tantangan konsep Barat modern menunjukan bahwa memang, konsep-konsep keilmuan yang dikembangkan peradaban Barat sekular merupakan tantangan terbesar bagi umat Muslim dewasa ini. Oleh sebab itu, mengenai Islam dan Barat, maka S.M.N. al-Attas menegaskan

\footnotetext{
${ }^{62}$ Lihat Peter D. Hershock, Marietta Stepaniants, dan Roger T. Ames (ed.), "Technology and Cultural Values on the Edge of the Third Millennium", (Honolulu: University of Hawaii Press, 2003), dalam Adian Husaini, Filsafat Ilmu, hlm. 40.

${ }^{63}$ Syed Muhammad Naquib al-Attas, Ma'na Kebahagiaan dan Pengalamannya dalam Islam, (Kuala Lumpur: ISTAC, 2002), pengantar Prof. Zainy Uthman, hlm. xxxv.

${ }^{64}$ Seyyed Hossein Nasr, The Need for a Sacred Science, (New York: State University of New York Press, 1993), hlm. 71.
} 
secara konseptual, bahwa antara keduanya terapat perbedaan yang fundamental sehingga akan menimbulkan konflik yang akan bersifat pemanen (a permanent confrontation). ${ }^{65}$ S.M.N. al-Attas menggambarkan pandangan alam (worldview) dan filsafat ilmu sekular Barat sebagai berikut:

"Contemporary science has evolved and developed out of a philosophy that science its earliest periods affirmed the coming into being of things out of what lies in latency in eternal matter. The world seen from this perspective is an independent, eternal universe; a selfsubsistent sistem evolving according to its own laws. The denial of the reality and existence of God is already implied in this philosophy. Its method are chiefly philosophic rationalism, wich tends to depend on reason alone without the aid of sense perception or experience; sekular rationalism, which while accepting reason tends to rely more on sense experience, and denies authority and intuition and reject Revelation and religion as sources of true knowledge; and philosophic empiricism or logical empiricism which bases all knowledge on observable facts, logical constructions and linguistic analysis. ${ }^{166}$

Sementara itu, di lembaga pendidikan Islam telah terjadi kekacauan (confusion) dalam ilmu-ilmu agama. Gejalanya, sudah menyebar apa yang disebut oleh Dr. Syamsuddin Arief sebagai "Kangker epistemologis". Kangker jenis ini telah melumpuhkan kemampuan menilai (critical power) serta mengakibatkan kegagalan akal (intellectual failure), yang pada gilirannya menggerogoti keyakinan dan keimanan, dan akhirnya menyebabkan kekufuran. ${ }^{67}$

Gejala orang yang mengidap kangker ini, diantaranya suka berkata, "Di dunia ini, kita tidak pernah tau Kebenaran Absolut. Yang kita tahu hanyalah kebenaran dengan ' $\mathrm{k}$ ' kecil." "Kebenaran itu relatif, truth claim bagi agama adalah berbahaya, dan tidak ada di dunia ini kebenaran final." "Agama itu mutlak, sedangkan pemikiran keagamaan relatif." Dan lain-lain.

Gejala kangker epistemologis seperti yang disebutkan di atas saat ini menjadi kurikulum utama di lembaga pendidikan Islam. Di sekolah-sekolah di tanamkan apa yang disebut dengan dikotomi "ilmu umum dan ilmu

\footnotetext{
${ }^{65}$ Adian Husaini, et. al., Filsafat Ilmu Perspektif Barat dan Islam, (Jakarta: Gema Insani, 2013), hlm. 41.

${ }^{66}$ Syed Muhammad Naquib al-Attas, Prolegomena to the Metaphysics of Islam, (Kuala Lumpur: ISTAC, 1995), hlm. 115.

${ }^{67}$ Syamsuddin Arief, Orientalis dan Diabolisme Pemikiran, (Jakarta: Gema Insani, 2008), hlm. 140.
} 
agama" serta pendidikan multikulturalisme. ${ }^{68}$ Misi utamanya ialah menamkan keyakinan bahwa Islam bukan satu-satunya agama yang benar. ${ }^{69}$ Di perguruan tinggi Islam diajarkan dan ditanamkan secara resmi pluralisme agama; keyakinan bahwa kebenaran ada pada semua agama. Konsekuensinya, maka akan dibenarkan pula pernikahan antar-agama, mengucapkan selamat natal kepada pemeluk Kristen, doa bersama/antar agama, merayakan hari raya agama lain, yang kemudian dikodifikasikan menjadi Fikih Lintas Agama. ${ }^{70}$

Mengenai perdebatan dikotomi ilmu dalam pemikiran Islam, yaitu pertentangan dikotomi ilmu dengan istilah kelompok ilmu "antroposentris" dihadapkan dengan kelompok ilmu "teosentris", sebagaimana Muliawan mengutip C.A. Qadir, menyatakan.

"Berdasarkan argumen epistemologi, ilmu pengetahuan antroposentris dinyatakan bersumber dari manusia dengan ciri khas akal atau rasio sedangkan ilmu pengetahuan teosentris dinyatakan bersumber dari Tuhan dengan ciri khas "kewahyuan". Maka terbentuklah pertentangan antara wahyu dan akal. Lebih jauh, pertentangan ini berkembang menjadi pertentangan antara dua jenis ilmu, yaitu agama dan filsafat. Agama yang menekankan pada pengetahuan kewahyuan dipertentangkan dengan filsafat yang menekaankan pada akal manusia". ${ }^{71}$

Maka, berbeda dengan epistemologi Barat yang hanya mengandalkan emperisme dan rasionalisme, epistemologi Islam mengakui empat sumber ilmu sekaligus, yaitu: indera, akal, intuisi, dan wahyu. Masing-masing sumber tersebut memiliki kadar kemampuan yang berbeda sehingga mereka tidak bisa dipisah-pisah dan harus digunakan secara proporsional. Indera penglihatan, misalnya, hanya mampu berfungsi pada frekuensi 400-700 nanometer. Indera pendengaran berfungsi pada frekuensi 20-20.000 kilohertz/detik. Jadi, disitulah diperlukan akal, yang juga mempunyai kemampuan terbatas. ${ }^{72}$ Dalam Istilah Ibn Khaldun:

\footnotetext{
${ }^{68}$ Lihat misalnya Prof. Dr. H. Dadang Kahmad, M. Si., Multikulturalisme Islam dan Media: Respon Ormas Isalm dan Peran Buletin Jumat Menyebarluaskan Gagasan Multikulturalisme, (Bandung: Pustaka Djati, 2013)

${ }^{69}$ Nashruddin Syarief, Konsep Ilmu dalam Islam, hlm. 50 mengutip dari karya Zakiyuddin Baidhawi, Pendidikan Agama Berwawasan Multikultural, (Jakarta: Erlangga, 2005).

${ }^{70}$ Nashruddin Syarief, Ibid, hlm. 50 mengutip dari karya Nurcholis Madjid dkk., Fikih Lintas Agama, (2005).

${ }^{71}$ Jasa Ungguh Muliawan, Pendidikan Islam Integratif: Upaya Mengintegrasikan Kembali Dikotomi Ilmu dan Pendidikan Islam, (Yogyakarta: Pustaka Pelajar, 2005), hlm. 204.

${ }^{72}$ Adian Husaini, et. al., Filsafat Ilmu, hlm. 48.
} 
"Sebagai timbangan emas dan perak, akal adalah sempurna. Tetapi masalahnya, bisakah timbangan emas dipakai untuk menimbang gunung?"73

Sejak digaungkan oleh S.M.N. al-Attas - saat bertindak sebagai keynote speaker - dalam konferensi Pendidikan Islam Internasional pertama di Kota Mekkah, pada tahun 1977, gerakan Islamisasi ilmu saat ini terus melaju. Berbagai upaya telah dilakukan. Sebab, Islamisasi ilmu adalah sebuah kebutuhan, itu pun jika Umat Islam dan negara-negara Muslim ingin meraih kejayaan dan kebahagiaan yang hakiki di dunia dan akhirat. ${ }^{74}$

\section{Keniscayaan Islamisasi Ilmu Pengetahuan Kontemporer}

S.M.N. al-Attas mencetuskan gagasan agar umat Islam melakukan Islamisasi terhadap ilmu pengetahuan kontemporer dengan mengislamkan simbolsimbol linguistik mengenai realitas dan kebenaran (reality and truth), setelah mengkaji nilai-nilai yang menyebabkan kerusakan keilmuan pada peradaban Barat yang juga berpotensi merusak umat Islam dan peradaban yang akan dibangunnya. S.M.N. al-Attas menerangkan bahwa Islamisasi ilmu pengetahuan adalah "Pembebasan manusia, mulai dari magik, mitos, animisme, dan tradisi kebudayaan, kebangsaan (yang bertentangan dengan Islam), dan kemudian dari penguasaan sekular atas akal dan bahasanya...Juga pembebasan dari control dorongan fisiknya yang cenderung sekular dan tidak adil terhadap hakikat diri atau jiwanya, sebab manusia dalam wujud fisiknya cenderung lupa terhadap hakikat diri atau jiwanya, sebab manusia dalam wujud fisiknya cenderung lupa terhadap hakikat dirinya yang sebenarnya, menjadi bodoh akan tujuan yang sebenarnya, dan berbuat tidak adil terhadapnya. Islamisasi adalah suatu proses menuju bentuk asalnya yang tidak sekuat proses evolusi dan devolusi" 75 .

Professor al-Attas beranggapan bahwa solusi dari permasalahan yang umat Islam hadapi adalah Islamisasi Ilmu Pengetahuan, yaitu dengan moneklatur "Islamisasi ilmu pengetahuan kontemporer" yang agak berbeda dengan konsep Islamisasi yang dilontarkan ilmuwan yang lain. ${ }^{76}$ Sebab menurut ia, pada awalnya semua ilmu ada pada bentuknya yang Islami. Akan tetapi, seiring dengan perkermbangan zaman, bentuk asli (fitrah) ilmu sedikit demi sedikit berubah. Perubahan itu terjadi bersamaan dengan

\footnotetext{
${ }^{73}$ Mulyadhi Kartanegara, Integrasi Ilmu, (Bandung: Mizan, 2005), hl. 100-115.

${ }^{74}$ Adian Husaini, et. al., Filsafat Ilmu, hlm. 48.

${ }^{75}$ Syed Muhammad Naquib al-Attas, Islam dan Sekularisme, hlm. 56; Wan Daud, Filsafat dan Praktik Pendidikan, hlm. 335-336.

${ }^{76}$ Tiar Anwar Bachtiar, Respon Pemikiran INSISTS, hlm. 283.
} 
proses sekularisasi masyarakat yang terjadi di Eropa yang beberapa ratus kemudian diekspor dan digembar-gemborkan kedunia Islam. Definisi sekulerisasi yang menurut Syed Muhammad Naquib Al-Attas paling sesuai adalah definisi yang diberikan oleh seorang teolog asal Belanda, Coernelius Van Peursen yang pernah menduduki kursi filsafat di Universitas Leiden. Sekularisasi difinisikan oleh Van Peursen sebagai "pembebasan seseorang, pertama dari kontrol religius dan kemudian metafisis, terhadap pemikirin dan bahasanya". ${ }^{77}$ Dalam pandangan Prof. Naquib al-Attas, ilmu pengetahuan Barat modern yang diproyeksikan melalui pandangan hidupnya, dibangun di atas visi intelektual dan psikologis budaya dan peradaban Barat. ${ }^{78}$ Menurutnya ada 5 faktor yang menjiwai budaya dan peradaban Barat. ${ }^{79}$ (1) Akal diandalkan untuk membimbing kehidupan manusia; (2) Bersifat dualistik terhadap realitas dan kebenaran; (3) Menegaskan aspek eksistensi yang memproyeksikan pandangan hidup sekular ; (4) Membela doktrin humanisme; (5) Menjadikan drama dan tragedi sebagai unsur yang dominan dalam fitrah dan eksistesi kemanusiaan. ${ }^{80}$

Saat Konferensi Internasional tentang pendidikan di Mekkah yang digelar pada tahun 1977, yang dihadiri oleh tokoh-tokoh pendidikan dunia Muslim, al-Attas diundang sebagai pembicara utama. Di dalam konferensi tersebut, al-Attas mengemukakan gagasannya tentang tantangan terbesar yang sedang dihadapi kaum Muslimin adalah sekularisasi ilmu pengetahuan. Ia menggulirkan gagasan Islamisasi ilmu pengetahuan sebagai solusinya. Tahun 1978, ia menulis buku Islam and Sekularism, yang lebih mempertajam lagi gagasannya. Selanjutnya, Pada tahun 1980, ia menulis kembali sebuah buku tentang The Concept of Education in Islam. Kemudian ide-idenya tentang Islamisasi ilmu pengetahuan pada tahun 1995 dibukukan dengan judul Prolegomena to the Methaphysics of Islam.

Dalam pandangan S.M.N. al-Attas, westernisasi ilmu adalah hasil dari kebingungan dan skeptisisme. Westernisasi ilmu telah mengangkat keraguan dan dugaaan ke tahap metodologi ilmiah. Bukan hanya itu, westernisasi ilmu juga telah menjadikan keraguan sebagai alat epistemologi yang sah dalam keilmuan. Menurutnya lagi, westernisasi ilmu tidak dibangun diatas wahyu dan kepercayaan agama. Namun dibangun diatas

\footnotetext{
${ }^{77}$ Syed Muhammad Naquib Al-Attas, Islam dan Sekulerisme, (Bandung: pustaka, 1981), hlm. 17.

${ }^{78}$ Adnin Armas, Krisis Epistemologi Dan Islamisasi Ilmu, hlm. 11.

${ }^{79}$ Syed Muhammad Naquib al-Attas, Islam And Secularism, hlm. 137.

${ }^{80}$ Lihat kritikannya didalam karyanya Prolegomena to The Metaphysics of Islam: An Exposition of The Wordview of Islam, (Kuala Lumpur: ISTAC, 1995), hlm. 88; 99-108.
} 
tradisi budaya yang diperkuat dengan spekulasi filosofis yang terkait dengan kehidupan sekular yang memusatkan manusia sebagai makhluk rasional. Akibatnya, ilmu pengetahuan dan nilai-nilai etika dan moral, yang diatur oleh rasio manusia, terus-menerus berubah. ${ }^{81}$

Islam merupakan agama sekaligus peradaban. ${ }^{82}$ Islam tidak melulu disebarkan karena pedang. Islam tersebar, menguasai dan menyelamatkan (mengislamkan) masyarakat-masyarakat di kawasan-kawasan yang didudukinya. Dalam Islam tidak dikenal eksploitasi sumber daya alam untuk dibawa ke daerah darimana Islam berasal. Tidak ada pertambahan kekayaan bagi jazirah Arab. Tidak ada kemiskinan akibat masuknya orang Muslim ke kawasan yang didudukinya. Daerah-daerah yang dikuasai atau diselamatkan umat Islam justru menjadi kaya dan makmur. Itulah watak peradaban Islam yang sangat berbeda dari peradaban Barat yang eksploitatif. $^{83}$

Setelah kita mengetahui secara mendalam mengenai pandangan alam atau pandangan hidup Islam dan Barat, maka proses Islamisasi baru bisa dilakukan. Oleh sebab itu, metodologi yang digunakan oleh S.M.N. alAttas dalam proses Islamisasi ilmu pengetahuan masa kini (The Islamization of present-day Knowledge), terdiri dari dua langkah atau proses yang saling berkaitan. Yaitu sebagai berikut:

a. Mengisolir unsur-unsur dan konsep-konsep kunci yang yang membentuk budaya dan peradaban Barat (5 unsur yang telah disebutkan sebelumnya), ${ }^{84}$ dan setiap bidang ilmu pengetahuan modern saat ini, khususnya dalam ilmu pengetahuan humaniora. Bagaimanapun ilmu-ilmu alam, fisika dan aplikasi harus diislamkan juga khususnya dalam penafsiran-penafsiran akan fakta-fakta dan formulasi teori-teori. ${ }^{85}$ Menurut S.M.N. al-Attas, jika tidak sesuai dengan pandangan hidup Islam, maka fakta menjadi tidak benar. ${ }^{86}$ Selain itu, ilmuilmu modern harus diperiksa dengan teliti. Ini mencakup metode, konsep, praduga, simbol dan ilmu modern; beserta aspek-aspek empiris dan rasional, dan yang berdampak kepada nilai dan etika, penafsiran historisitas ilmu tersebut, bangunan teori ilmunya, praduganya berkaitan dengan dunia, dan rasionalitas proses-proses ilmiah, teori ilmu tersebut tentang alam semesta,

\footnotetext{
${ }^{81}$ Syed Muhammad Naquib al-Attas, Islam And Secularism, (Kuala Lumpur: ISTAC, 1993, edisi 2), hlm. 133-135.

${ }^{82}$ Wan Daud, The Educational Philosophy, hlm. 298.

${ }^{83}$ Lihat Hamid Fahmy Zarkasyi, Peradaban Islam: Makna dan Strategi Pembangunannya, (Ponorogo: CIOS UNIDA, 2015, Cet. II), hlm. 9.

${ }^{84}$ Lihat juga halaman 3-4 dari Paper ini.

${ }^{85}$ Wan Daud, Educational Philosophy, hlm. 313.

${ }^{86}$ Wan Daud, Ibid, hlm. 313.
} 
klasifikasinya, batassannya, hubungan dan kaitannya dengan ilmu-ilmu lainnya serta hubungannya dengan sosial harus diperiksa dengan teliti. ${ }^{87}$

b. Memasukkan unsur-unsur (elements) Islam beserta konsep-konsep kunci dalam setiap bidang dan ilmu pengetahuan saat ini yang relevan. Jika proses tersebut selesai dilakukan, maka Islamisasi akan membebaskan manusia dan magic, mitologi, animisme, tradisi budaya nasional yang bertentangan dengan Islam, dan kemudian dari control sekular kepada akal dan bahasanya. Islamisasi akan membebaskan akal manusia dari keraguan (syakk), dugaan (dzann) dan argumenasi kosong (mira') menuju keyakinan akan kebenaran mengenai realitas spiritual, intelegible dan materi. ${ }^{88}$ Islamisasi akan mengeluarkan penafsiran-penafsiran ilmu pengetahuan kontemporer dan idiologi, makna dan ungkapan sekular. ${ }^{89}$

Dengan dimasukannya unsur-unsur serta elemen-elemen Islam tersebut, maka selanjutnya akan merubah tafsiran, bentuk-bentuk, dan nilainilai konseptual isi pengetahuan. ${ }^{90}$ Kemudian, S.M.N. al-Attas juga merincikan dan memasukan beberapa konsep dasar (fundamental) Islam yang mesti dituangkan serta diejawantahkan ke dalam setiap cabang ilmu apa pun yang dipelajari oleh umat Islam, ${ }^{91}$ sebagaimana berikut:

a. Konsep agama (Din), b. Konsep manusia (Insan), c. Konsep ilmu ('Ilm dan Ma'rifah), d. Konsep kearifan (Hikmah), e. Konsep keadilan ('Adl), f. Konsep perbuatan yang benar (Amal sebagai adab), g. Konsep universitas (Kulliyah-Jami'ah)

Menafsirkan konsep-konsep fundamental di atas, Rahmad Yulianto dan Achmad Baihaki menerangkan bahwa di dalam penerapan peraktis atau implementasinya sangat berkaitan erat dengan dunia pendidikan. Konsep agama ( $\mathrm{din})$ menunjukkan kepada maksud mencari pengetahuan dan keterlibatan dalam proses pendidikan. Konsep manusia (insan) kepada ruang lingkup. Konsep ilmu ('ilm dan ma'rifah) mengacu pada isi. Konsep kearifan (hikmah) kepada kreteria dalam hubungan dengan konsep manusia

\footnotetext{
${ }^{87}$ S.M.N. al-Attas, Prolegomena to the Metaphysics of Islam, (kuala Lumpur: ISTAC:, 1995), hlm. 114.

${ }^{88}$ Wan Daud, The Educational Philosophy, hlm. 312.

${ }^{89}$ S.M.N. al-Attas, The Concept of Education, hlm. 43.

90 Lihat Rahmad Yulianto dan Achmad Baihaki, "Islamisasi Ilmu Pengetahuan Dalam Perspektif Syed Muhammad Naquib al-Attas”, Jurnal Studi Agama-Agama Al-Hikmah, Vol. 4, No. 1, Thn. 2018, hlm. 15.

91 Syed Muhammad Naquib al-Attas, Islam dan Sekularisme, (Bandung: Pustaka, 1981), hlm. 233.
} 
(insan) dan ilmu ('ilm dan ma'rifah). Konsep keadilan ('adl) kepada pengembangan dalam hubungannya dengan konsep kearifan (hikmah). Konsep perbuatan yang benar (amal sebagai adab) kepada metode dalam hubungannya dengan konsep agama (din), konsep keadilan ('adl). Konsep universitas (kulliyah jami'ah) dianggap penting kerena berfungsi sebagai implementasi semua konsep itu dan menjadi model sistem pendidikan untuk tingkat rendah. ${ }^{92}$

Kerangka Islamisasi ilmu pengetahuan versi S.M.N. al-Attas secara tegas memang disebutkan beliau bahwa sumber-sumbernya adalah berasal dari pemikiran para sufi yang mamppu memberikan penelasan metafisika secara memadai. Professor al-Attas menyimpulkan dengan sangat yakin dalam disertasinya tentang Hamzah Fansuri -yang menginspirasi munculnya ide Islamisasi ilmu pengetahuan ini-sebagai berikut.

"...that it through Sufism that the highly intellectual and rationalistic religious spirit entered the receptive minds of the people, effecting a rise of intellectualism and rationalism not manivested in pre-Islamic times...revolutionalizing the MalayIndonesian worldview, turning it away from a crumbling world of mythology...to the world of intelligence, reason, and order; that it emphasized the belief in a God whose power is governed by wisdom, whose creative will works in accordance with reason; that it emphasized Man as the epitome of creation, whose very essence is rationality which is connecting link between him and Reality; that finally -to use a pregnant remark- it prepared the Malay-Indonesians, in a sense, for the modern world to come". 93

Sufisme di dunia Melayu-Indonesia bagi S.M.N. al-Attas -seperti tergambar dalam karya-karya Hamzah Fansuri- dianggap telah berhasil mengubah pandangan alam (worldview) masyarakat di kawasan ini yang tadinya penuh dengan mitologi, baik karena pengaruh kepercayaankeppercayaan lama maupun karena pengaruh ajaran Hindu-Budha yang datang belakangan, menjadi worldview Islami. Ini merupakan contoh paling baik dalam proses Islamisasi di Nusantara. Hal serupa juga terjadi ketika Rasulullah Saw mengislamkan Jazirah Arab. Konsep-konsep bahasa Arab

\footnotetext{
${ }^{92}$ Rahmad Yulianto dan Achmad Baihaki, "Islamisasi Ilmu Pengetahuan Dalam Perspektif Syed Muhammad Naquib al-Attas”, Jurnal Studi Agama-Agama Al-Hikmah, Vol. 4, No. 1, Thn. 2018, hlm. 16.

93 Syed Muhammad Naquib al-Attas, The concept of Education in Islam, makalah yang disampaikan pada konferensi Dunia tentang Pendidikan Islam di Mekkah tahun 1977, (1977), hlm.194-195; Wan Daud, The Educational Philosophy and Practice Syed Muhammad Naquib al-Attas, (Kuala Lumpur: ISTAC, 1998), hlm. 295; Wan Daud, filsafat dan Praktik Pendidikan Islam Syed M. Naquib al-Attas, (Bandung: Mizan, 2003), hlm. 321.
} 
yang mencerminkan worldview masyarakat Arab Jahiliyyah diubahsesuaikan dengan ajaran-ajaran Islam yang dibawa Sang Rasul. Sehingga, worldview yang melatari pemikiran bangsa Arab menjadi Islami sebagaimana tercermin dalam makna-makna bahasanya.

Penerimaan Tasawuf oleh S.M.N. al-Attas, bahkan dianggap sebagai sumber utama dalam proses Islamisasi ilmu, bertentangan dengan konsep Reformisme-Salafiyyah yang cenderung menolak tasawuf dan mengklaimnya sebagai salah satu penyebab kemunduran Kaum Muslimin..$^{94}$

Amran Muhammad -salah seorang murid Professor al-Attas di ISTAC- memaparkan langkah-langkah kongkrit dalam proses Islamisasi ala S.M.N. al-Attas sebagai berikut ini. ${ }^{95}$

Pertama, Islamisasi harus bermula dari individu yang harus dibebaskan dari pemikiran magis, mitologis, animis, kultur anti Islam, serta pemikiran sekular. Islamisasi individu ini selain itu juga mesti dapat menempatkan diri pada tempatnya sebagai manusia. Hal ini dapat dilakukan ketika manusia memahami dengan baik fitrah insaninya, baik hubungannya dengan Tuhan, wahyu, alam semesta, maupun dengan sesama manusia sendiri. Kepahaman ini akan melahirkan manusia "beradab" (mamiliki adab) yang merupakan tujuan utama pendidikan bagi manusi. Dalam proses ini yang menjadi teladan utama adalah bagaimana Nabi Muhammad Saw mengislamkan masyarakat Jahiliyyah dengan bermula mengislamkan individu-individu yang nanti akan menjadi para sahabatnya.

Kedua, agenda berikutnya dalam proses Islamisasi adalah mengislamkan bahasa karena bahasa inilah yang memengaruhi akal dan pandangan alam seseorang. S.M.N. al-Attas dalam konteks ini, juga menyerap pengalaman Nabi Muhammad Saw tatkala mengislamkan bangsa Arab. Usaha pertama yang dilakukannya dalam berdakwah kepada msyarakat Arab yaitu dengan mengislamkan bahasa Arab yang konsepkonsepnya sudah dipenuhi dengan konsep Jahiliyyah menjadi bahasa Arab Qur'ani. Terkandung dalam bahasa Arab yang baru ini pembendaharaan kata yang serupa dengan Arab-Jahiliyyah, tetapi diberi makna baru berdasarkan wahyu yang diturunkan kepada Nabi Saw. Proses ini terjadi

${ }^{94}$ Lihat Ismail Raji al-Faruqi, Islamization of Knowledge: General Principles and work Plan, (Virginia USA: IIIT, 1995), hlm. 23-29.

95 Pandangan Amran Muhammad tentang kritik atas Islamisasi al-Faruqi ini diambil dari Jurnal al-Hikmah yang diterbitkan ISTAC semasa masih dipimpin al-Attas, yaitu edisi 3 Juli/Agustus 1996. Gagasan pada bagian ini diringkas dari makalah beliau di atas yang berjudul "Menjernihkan Gagasan Islamisasi Ilmu Prof. al-Attas". 
begitu kuat sehingga bahasa Arab yang telah mengalami proses Islamisasi memiliki pembendaharaan kosa kata utama yang membentuk worldview seorang Muslim. Bahkan karena kuatnya proses Islamisasi makna bahasa itu, ketika bahasa Arab-Islam tersebar ke berbagai penjuru dunia, bahasa ini ikut mengislamkan bahasa setempat. Inilah yang terjadi pada bahasa Melayu, Urdhu, Turki, Jawa, Sunda dan Parsi setelah kedatangan Islam. Kata-kata kunci dengan makna Islami dalam bahasa Arab-Islam seperti Allah, wahyu, iman, ilmu, amal, makrifah, adil, adab, mukadimah, hikmah, ${ }^{96}$ dan sebagainya menjadi sangat familiar pada bahasa-bahasa setempat yang diislamkan, termasuk bahasa Melayu. Bahasa Melayu sendiri telah menyerap sangat banyak unsur-unsur Arab-Islam sehingga bahasa ini menjadi bahasa yang mudah membentuk alam-pikiran Islami pada masyarakat Melayu.

Ketiga, dari Islamisasi bahasa akan segera beralih pada Islamisasi worldview (pandangan alam). Pandangan alam yang telah "terIslamkan" akan membentuk semesta berpikir komprehensif mengenai realitas yang dihadapi manusia berdasarkan wahyu Allah SWT. Dalam kerangka pembentukan pandangan alam Islam ini, S.M.N. al-Attas menulis berbagai buku dengan tema-tema pokok yang berkaitan dengan Islamic Worldview. Buku paling penting dalam tema ini adalah Prolegomena to the Metaphysics of Islam (1995). S.M.N. al-Attas dalam buku tersebut memperkenalkan konsepkonsep kunci Islam untuk menafsirkan realitas yang dihadapi manusia (Muslim).

Keempat, setelah pandangan alam (worldview) yang Islami terbentuk dalam pikiran setiap orang, maka secara natural dari situ akan lahir ilmuilmu yang terIslamkan. Bagi Professor al-Attas, ilmu itu berada dalam akal manusia bukan berada di luar diri mereka. Oleh karena itu, sebagai prasyarat lahirnya ilmu-ilmu yang terIslamisasi adalah mengislamkan akal dan worldview para ilmuwannya. Terjadi pula perbedaan pada titik ini dengan konsepsi Ismail $R$. al-Faruqi yang telah mengedepankan mengislamkan disiplin-disiplin ilmu melalui pengIslaman metodologi. Al-

\footnotetext{
${ }^{96}$ Hal-hal lain yang merupakan konsep-konsep kunci dalam Islamic Worldview dibahas secara panjang lebar oleh S.M.N. al-Attas dalam buku Prolegomena to the Metaphysics of Islam (1995) seperti konsep tentang agama, nabi, wahyu, jiwa manusia, kebahagiaan, dan sebagainya. Terutama buku On Quiddity and Essence, (Kuala Lumpur: ISTAC, 1990). Risalah tersebut bersama risalah-risalah yang lainnya kemudian dikompilasi dalam satu buku berjudul Prolegomena di atas. Lihat Prolegomena to the Metaphysics of Islam, hlm. 217 165. Bandingkan dengan Syamsuddin Arif, sebuah makalah yang berjudul: "Being, Essence, and Quiddity: A Review Essay on Syed Muhammad Naquib al-Attas".
} 
Faruqi dianggap keliru sebab gagal memahami bagaimana berbagai disiplin ilmu itu terbentuk.

Ilmu-ilmu tradisional-tidak sebagaimana disiplin kontemporerIslam, sudah sejalan dengan worldview Islam. Ini pun dalam mengislamkan ilmu-ilmu kontemporeer harus mengislamkan terlebih dahulu metafisika, kerangka filsafat dan epistemologi ilmu-nya, bukan secara tiba-tiba mengislamkan metodologinya yang berada pada level teknis. Sebab, kalau mengacu pada konflik atau pertentangan antara Barat-Islam yang sebenarnya, justru bukan pada metodologinya melainkan sistem nilai (value sistem) dan pandangan alam (worldview) yang meliputi persoalan metafisika, falsafah, serta epistemologi.

Adapun menurut Roshnani Hashim, tujuan yang hendak dicapai dengan terealisasinya gagasan Islamisasi ilmu pengetahuan, ${ }^{97}$ diantaranya:

a. Mengeluarkan ilmu pengetahuan kontemporer penafsiran-penafsiran yang berlandaskan ideologi, makna dan ungkapan sekuler yang bertentangan dengan ajaran Islam.

b. Menjadikan Islam sebagai alternatif epistimologi Barat.

c. Mengembangkan ilmu yang hakiki untuk membangun pemikiran dan rohani pribadi muslim yang dapat meningkatkan keimanannya dan ketaqwaannya kepada Allah SWT.

d. Islamisasi ilmu akan melahirkan keamanan, kebaikan, keadilan dan kekuatan keimanan.

e. Menghilangkan konsep dikotomi ilmu yang berakibat pada pemisahan antara ilmu agama dan ilmu umum, karena pada hakekatnya ilmu bersumber dari yang maha tunggal yaitu Allah SWT.

Konsep Islamisasi ilmu pengetahuan yang dirasakan paling mendasar dan menyentuh akar permasalahan ilmu adalah konsep dengan pendekatan yang berlandaskan paradigma Islam. ${ }^{98}$ Konsep Islamisasi ilmu seperti ini yang disampaikan pertama kali secara sistematis oleh Professor alAttas. Bahkan secara khusus ia menyebut permasalahan Islamisasi adalah permasalahan mendasar yang bersifat epistemologis. ${ }^{99}$ Dengan demikian, konsep Islamisasi ilmu pengetahuan secara paradigma ini akan berakar kuat dan sesuai dengan jiwa Islam.

Islamisasi ilmu pengetahuan itu haruslah dibangun di atas kerangka metafisika, falsafah, dan episemologi yang benar menurut pandangan Islam.

\footnotetext{
${ }^{97}$ Rosnani Hashim, Gagasan Islamisasi Ilmu, hlm. 31.

${ }^{98}$ Budi Handrianto, Islamisasi Sains, hlm. 177.

${ }^{99}$ Wan Daud, The Educatioanl Philosophy, hlm. 311.
} 
Kerangka mendasar ini haruslah dipahami dengan baik dan jelas oleh para cendikiawan dan ilmuwan Muslim sebelum diterapkan dalam berbagai disiplin ilmu masing-masing yang beragam corak, macam dan jenisnya. Oleh karena itu, setiap intelektual Muslim mestilah memahami agama mereka sendiri terlebih dahulu, memiliki worldview Islam yang tepat, menguasai dengan benar kerangka metafisika Islam, hingga seterusnya melakukan program Islamsasi ilmu. Metafisika dan worldview Islam ini hanya dapat diperoleh dengan memahami tradisi keilmuan Islam itu sendiri. Hal tersebut pasti tidak bisa kita lakukan bilamana filsafat Islam dan tasawwuf di tolak. Sebagaimana halnya Ismail Raji al-Faruqi dan kelompoknya -yang dipengaruhi oleh Reformis-Salafiyyah- akan menghadapi kesulitan ini karena kelompok ini sejatinya menolak filsafat Islam, tasawwuf dan kalam yang benar sesuai Islam. Dengan upaya Islamisasi ilmu pengetahuan yang cukup massif ini, diharapkan kehidupan keislaman di masyarakat intelektual, khususnya di Tanah Air kita tercinta, Indonesia semakin meningkat kualitasnya. Dan kebangkitan Islam Insya Allah akan dimulai serta disongsong dari sana.

\section{Simpulan}

Islamisasi ilmu pengetahuan adalah upaya mengembalikan kemurnian ilmu yang telah dicemari oleh virus sekularisme dengan cara memasukan nilainilai Islam ke dalam disiplin ilmu-ilmu kontemporer yang telah cenderung sekular dan bebas nilai serta pembebasan dari penguasaan sekular atas akal dan bahasa. Sementara itu, ilmu pengetahuan dalam peradaban Barat modern beserta aktualisasi ilmu-ilmu kontemporernya, ternyata tidak netral dan sarat akan nilai pengalaman dan proyeksi pandangan alam peradaban Barat yang di dasarkan mitologi, filsafat, animisme, kebudayaan Kebangsaan (yang menyimpang dari Islam), Mitos, dan lain sebagainya. Jadi, ilmu pengetahuan modern harus di-Islamkan. Sebagai kesimpulan, untuk menjawab tantangan hegemoni westernisasi ilmu yang sedang melanda peradaban dunia saat ini, umat Islam memerlukan Islamisasi Ilmu. Adapun pemikiran Prof. S.M.N. al-Attas tentang konsep Islamisasi ilmu pengetahuan kontemporer bila diuraikan adalah sebagai berikut.

Dalam ilmu pengetahuan Barat modern sekular terdapat beberapa "Virus" yang terkandung di dalamnya yang menjadi cikal bakal munculnya suatu konsepsi akan perlunya Islamisasi ilmu pengetahuan, diantaranya yaitu; (1) Akal diandalkan untuk membimbing kehidupan manusia; (2) Bersikap dualistik terhadap realitas dan kebenaran; (3) Menegaskan aspek eksistensi yang memproyeksikan pandangan hidup sekuler; (4) Membela 
doktrin humanisme; (5) Menjadikan drama dan tragedi sebagai unsur-unsur yang dominan dalam fitrah dan eksistensi kemanusiaan.

Pandangan Syed Muhammad Naquib al-Attas terhadap ilmu pengetahuan Islam dan Barat, Islam tidak berdasarkan dikatomis seperti obyektif-subyektif, historis-normatif, tekstual-kontekstual. Akan tetapi realitas dan kebenaran dipahami dengan metode yang menyatukan (tauhid) dimana terdapat kesatuan antara kaidah induktif dan deduktif, empiris, serta rasional. Dalam Islam, realitas dan kebenaran bukan semata-mata pikiran tentang alam indrawi dan peranan manusia dalam sejarah, sosial, politik, dan budaya seperti halnya yang ada dalam peradaban Barat sekular mengenai dunia yang hanya memberikan perhatian terhadap dunia empiris saja. Akan tetapi, lebih dari itu, yakni memaknai realitas dan kebenaran berdasarkan kajian metafisis terhadap dunia yang empiris dan non empiris. Oleh sebab itu, Islam mencangkup aspek dunia dan akhirat, yang mana aspek dunia tidak boleh terpisah dan harus korelasikan dengan cara yang sangat mendalam kepada aspek akhirat, dengan keyakinan bahwa aspek akhirat merupakan yang terakhir dan final. Islam bersumber kepada wahyu yang didukung oleh akal dan intuisi. Substansi keimanan dan pengalaman ibadahnya, doktrin serta sistem teologinya telah ada dalam wahyu dan dijelaskan oleh Nabi Muhammad SAW.

Dalam displin ilmu filsafat Islam, Syed Muhammad Naquib AlAttas, yang menyentuh berbagai disiplin ilmu agama, pendidikan dan sains termasuk diantaranya yang paling kreatif dan terbaik dalam khazanah pemikiran Islam kontemporer yang mendifinisikan, mengkonseptualisasikan, dan menjabarkan inti, arti, dan muatan pendidikan Islam, serta metode Islamisasi ilmu pengetahuan kontemporer, lalu hakikat dan pendirian universitas Islam, serta formulasi dan sistematis dan filosofis. Semua gagasan ini merupakan sesuatu yang fundamental untuk menghidupkan kembali ilmu-ilmu agama, yang 900 tahun lalu berusaha dicapai oleh Imam al-Ghazali dan juga merupakan upaya yang brilliant, cerdas dan cemerlang, serta sophiscated atau 'canggih' dalam upaya menghadapi hegemoni keilmuan peradaban Barat modern sekular untuk kelak menyongsong peradaban Islam di masa depan yang gemilang.[] 


\section{DAFTAR PUSTAKA}

Al-Attas, Syed Muhammad Naquib. Ma'na Kebahagiaan dan Pengalamannya dalam Islam, Kuala Lumpur: ISTAC, 2002.

, The concept of Education in Islam, makalah yang disampaikan pada konferensi Dunia tentang Pendidikan Islam di Mekkah tahun 1977 ,

Islam and Secularism, Kuala Lumpur: ISTAC, 1995.

Islam the Concept of Religion and the Foundation of Ethics and Morality, Kuala Lumpur: IBFIM, 2013.

, The Oldest Known Malay Manuscript: A $16^{\text {th }}$ Century Malay Translation of the 'Aqa'id of al-Nasafi, Kuala Lumpur: University of Malaya Publications Department, 1988.

Islam, Secularism, And the Philosophy of The Future, London \&New York: Mansell publishing Limited, 1985.

Islam Dan Sekularisme, Penerjemah Dr. Khalif Muammar, M.A., Bandung: PIMPIN, 2010.

Risalah Untuk Kaum Muslimin, Kuala Lumpur: ISTAC, 2001.

Prolegomena to the Methaphisic of Islam, Kuala Lumpur: ISTAC, 2001).

Al-Banna, Gamal. al-Ta'addudiyyah Fi Mujtama' Islami, terj. Tim MataAir Publishing, Pluralitas dalam Masyarakat Islam, Jakarta: MataAir Publishing, 2006, cet. I.

Al-Faruqi, Ismail Raji. Islamization of Knowledge: General Principles and work Plan, Virginia USA: IIIT, 1995.

Alatas, Ismael Fajrie. konsep ilmu dalam Islam, Jakarta: Diwani Publising, 2006.

Al-Rasyidin dan Nizar, Filsafat Pendidikan Islam: Pendekatan Historis, Teoritis, dan Praktis, Jakarta: Ciputat Press, 2002.

Abdullah, Abdur Rahnman Haji. Pemikiran Islam di Malaysia: Sejarah dan Aliran, Jakarta: Gema Insani Press, 1997.

Abu Zayd, Nasr Hamid. Mafhum al-Nash: Dirasah fi 'Ulum al-Qur'an, Beirut: al-Markaz al-Tsaqafiy al-'Araby, 1994.

Azami, M.M. The History of the Quranic Text: From Revalation to Compilation, A Comparative Study with the Old and New Teastements, Terj. Dr Ugi Suharto, dkk. Jakarta: GIP, 2005, cet.II.

Andries,, Flavius Floris. "Kisah Ibrahim Dalam Tradisi Islam: Suatu Kajian Eksegesik Terhadap Surat Ali Imran; $64-69$ dan Relevansinya Baagi 
Pluralisme Agama", Jurnal Studi Ilmu-Ilmu al-Qur'an dan Hadis, Vol. 13, No. 1, Januari 2012, hlm. 99-122.

As-Syaukani , Imam Muhammad ibn 'Ali ibn Muhamad (w. 1255 H), Irsyad al-Fuhul Ild Tahqiq al-Haqqim 'Ilmi al-Ushul, Beirut: Dar al-Kotob al'Ilmiyyah, 1994.

Arif, Syamsuddin. Orientalis dan Dioabolisme Pemikiran, Jakarta: GIP, 2005.

makalah "Being, Essence, and Quiddity: A Review Essay on Syed Muhammad Naquib al-Attas".

Acikgence, Alparslan. Islamic Science: Towards Definition, Kuala Lumpur: ISTAC, 1996.

-.., Scientific Thought and Itss Burdens: an Essay in History and Philosophy of Science, Istambul: Fatih Universitesi Yiyinlari, 2000.

Armas, Adnin. "Sang Ilmuwan dan Gagasannya," Harian Umum Republika, 12 Maret 2009.

.manana Metafisika al-Attas", Jurnal Pemikian dan Peradaban Islam ISLAMIA, Vol. XI, No. 2, Agustus, 2017, hlm. 29-35. , Krisis Epistemologi Dan Islamisasi Ilmu, Ponorogo: CIOS UNIDA, 2015.

Bachtiar, Tiar Anwar. Respon pemikiran INSISTS (Institute for the study of Islamic Thought and Civilaations) Terhadap Pemikian Liberal Di Indonesia Tahun 2003-2012, Disertasi Doktoral Universitas Indonesia, Depok, 2015.

Bullock, Allan, et.all, The Fontana Dictionary of Modern Thought, $2^{\text {nd }}$ Ed., London: Fontana, 1988.

Bagus, Lihat Lorens. Kamus Filsafat, Jakarta: Gramedia Pustaka Utama, 2005, Cet. 6.

Blackburn, Simon. Oxford Dictionary of Philosophy, UK: Oxford University Press, 1996, s.v. relativism.

Damyati, Akhmad Rofi'i. "Makna dan Hakikat Wujud Dalam Pemikiran alAttas", Jurnal Pemikiran dan Peradaban Islam ISLAMIA, Vol. XI, No. 2, Agustus 2017, hlm.36-46.

Geertz, Clifford. The Implementation of Cultures: Selected Essays, penerjemah F. Budi Hardiman, Yoyakarta: Kanisius, cet. 9, 2003.

Handrianto, Budi. Ide Islamisasi Ilmu pengetahuan, Makalah Kuliah Pasca Sarjana Universitas Ibn Khaldun Bogor, 2007.

Islamisasi Sains: Sebuah Upaya Mengislamkan Sains Barat Modern, Jakarta: Pustaka Al-Kautsar.

Husaini, Adian. Wajah Peradaban barat: Dari Hegemoni Kristen ke Dominasi Sekular-Liberal, Jakarta: GEMA INSANI, 2005. 
(ed), Islamic Worldview: Bahan-Bahan Kuliah Di Program Pendidikan Dan Pemikiran Islam Pasca Sarjana Universitas Ibn Khaldun.

...m.n.m.n.m. Mengapa Barat Menjadi Sekuler-Liberal?, Ponorogo: CIOS UNIDA, 2007.

manem, et. al., Filsafat Ilmu Perspektif Barat dan Islam, Jakarta: Gema Insani, 2013.

............... Hegemoni Kristen-Barat Dalam Studi Islam Di Perguruan Tinggi, Jakarta: GIP, 2006, cet. I.

Hasanah, Qoriatul. "Kritikus Hadis Perempuan: Studi Atas Tujuan dan Metode Kritik 'Aisyah R.A. terhadap Hadis-Hadis tentang Perempuan”, Jurnal Studi Ilmu-Ilmu al-Qur'an dan Hadis, Vol. 9, No. 1, Januari 2008, hlm. 123-146.

Hasan, Nur. "Kritik Islamic Werldview Syed Muhammad Naquib al-Attas Terhadap Western Worldview", Jurnal Studi KeIslaman MARAJI' Vol. 1, No. 1, September 2014, hlm. 120.

Hasib, Kholili. Kritik Atas Konsep Abrahamic faiths Dalam Studi Agama, Ponorogo: CIOS UNIDA, 2010, Cet. I.

Hendricks, Vincent E. Mainstream and Formal Epistemologi, Cambridge: Cambridge University Press, 2006.

Hamdani, M.A., Filsafat Sains, (Bandung: CV. Pustaka Setia, 2011), hlm. $151-153$.

Jawahir, "Syed M. Naquib al-Attas: Pakar Agama, Pembela Aqidah, dan Pemikir Islam yang DIpengaruhi Paham Orientalis", dalam Panji Masyarakat, No. 603, Edisi 21-28 Februari 1989, hlm. 32.

Jonathan Ree (ed.), The Concise Encyclopedia of Western Philosophy, $3^{\text {rd }}$ Edition, New York: Routledge, 2005.

Kartanegara, Mulyadhi. Integrasi Ilmu, Bandung: Mizan, 2005.

Khairurrijal, "Filsafat Bahasa Kontemporer dan Kriik al-Attas", Jurnal Pemikiran dan Peradaban Islam ISLAMIA, Vol. XI, No. 2, Agustus 2017, hlm. 47-71.

Kahmad, Prof. Dr. H. Dadang, M. Si., Multikulturalisme Islam dan Media: Respon Ormas Isalm dan Peran Buletin Jumat Menyebarluaskan Gagasan Multikulturalisme, Bandung: Pustaka Djati, 2013.

Kania, Dinar Dewi. "Pemikiran Epistemologi al-Attas", Jurnal Pemikian dan Peradaban Islam ISLAMIA, Vol. XI, No. 2, Agustus, 2017, hlm. 16.

Luthfiyah, Nafsiyatul.” Feminisme Islam di Indonesia," Jurnal Esensia, Vol. 16, no. 1, April 2015, hlm. 75-88. 
Mardhatillah, Masyithah. "Semangat Egalitarian al-Qur'an dalam Otoritas Menginisiansi dan Prosedur Perceraian," Jurnal Esensia, Vol. 16, no. 1, April 2015, hlm. 1-14.

Muqtada, Muhammad Rikza. "Makna Kalalah dan Penindasan Hak Perempuan,” Jurnal Esensia, Vol. 16, no. 1, April 2015, hlm. 29-42.

Muhammad, Husein. "Gagasan Tafsir Feminis", Jurnal Studi Ilmu-Ilmu alQur'an dan Hadis, Vol. 13, No. 1, Januari 2012, hlm. 23-38.

M. Yusron, dkk., Studi Kitab Tafsir Kontemporer, Yogyakarta: TH-Press, 2006. Mulyono, Edi, M. Ag., Belajar Hermeneutika, Yogyakarta: IRCIsoD, 2012.

Muliawan, Jasa Ungguh. Pendidikan Islam Integratif: Upaya Mengintegrasikan Kembali Dikotomi Ilmu dan Pendidikan Islam, Yogyakarta: Pustaka Pelajar, 2005.

Novayani, Irma. "Islamisasi Pengetahuan Meurut Pandangan Syed M. Naquib alAttas dan Implikasi Terhadap Lembaga Pendidikan Interrnational Institute Of Islamic Thought Civilazation (ISTAC)," Jurnal AlMuta'aliyah STAI Darul Kamal NW Kembang kerang Volume I No 1 Tahun 2017 , hlm. 76.

Nasir , Mohammad Nasrin \& Malki Ahmad Nasir, Sains Islam: Konsepsi Baharu Hubungan Sains dengan Agama, Negeri Sembilan Malaysia: USIM, 2016.

Van Melsen, Prof. Dr. A.G.M. Wetenschap en Verantwoodelijkheid, terj. Dr. K. Bertens, Ilmu Pengetahuan dan Tanggung Jawab kita, Jakarta: PT. Gramedia, cet. 2, 1992.

Surakhmad, Winarno. Pengantar Penelitian Ilmiah, Bandung: Tarsito, 2004.

Sharifah al-Attas (ed.), Islam and the Challenge of Modernity, Proceeding of the Inaugural Symposium on Islam and the Challenge of Modernity: Historical and Contemporary Context, Kuala Lumpur August, 1-5, 1994, Kuala Lumpur, ISTAC, 1996.

Suriasumantri, Jujun. Ilmu dalam Perspektif, Jakarta: Yayasan Obor Indonesia, 2009, cet. 17.

, Filsafat Ilmu: Sebuah Pengantar Populer, Jakarta: Pustaka Sinar Harapan, 2010, cet. 22.

Sirry, Mun'im. Islam Revisionis: Kontestasi Agama Zaman Radikal, Yogyakarta: Suka Press, 2018.

Syah, Hidayat. Pengantar Umum Metodologi penelitian Pendidikan Pendekatan Verifikatif, (Pekanbaru: Suska Press, 2010).

Salahuddin, Henri. Al-Qur'an Dihujat, Jakarta: Al-Qalam, 2007.

Seyyed Hossein Nasr, The Need for a Sacred Science, New York: State University of New York Press, 1993. 
Tafsir, Ahmad. Filsafat Ilmu: Mengurai Ontologi, Epistemologi, dan Aksiologi Pengetahuan, Bandung: Remaja Rosda Karya, 2013, cet. IIV.

Thoha, Anis Malik. Tren Prularisme Agama, Jakarta: Perspektif, 2005.

Fumerton, Richard. Epistemology, Oxford: Blackwell Publishing, 2005.

Wan Daud, Wan Mohd Noor. The Educational Philosophy and Practice Of Syed Muhmmd Naquib al-Attas: An Expesition Of The Original Concept Of Islamization, Kuala Lumpur: ISTAC, 1998.

, Filsafat dan Praktek Pendidikan Islam Syed Muhammad Naquib alAttas, Bandung; Mizan, 2003.

Webb , Jennifer M. (ed.), Powerful Ideas: Perspectif on the Good Society, (Victoria, The Cranlana Program, 2002), vol 2.

Yulianto, Rahmad \& Achmad Baihaki, "Islami Ilmu Pengetahuan Dalam Perspektif Syed Muhammad Naquib al-Attas", Jurnal Studi AgamaAgama AL-Hikmah, Vol. 4, No. 1, 2018.

Zarkasyi, Hamid Fahmy et.al, Membangun Peradaban dengan Ilmu, Jakarta: Kalam Indonesia, 2010.

.m.m.m.n.m. "Islam sebagai Pandangan Hidup", dalam Tantangan Sekularisasi dan Liberalisasi di Dunia Islam, ed. Tim KB Press, Jakarta: Khairul Bayan, 2004

.m.m.m.m. Al-Ghazali's Concept of Causality; With Reference to His Interpretations of Reality and Knowledge, terj. Burhan Ali \& Yulianingsih Riswan, Kausalitas Alam atau Tuhan? Membaca Pikiran Religio-Saintifik alGhazali, Ponorogo: UNIDA Gontor Press, 2018.

"Worldview Sebagai Asas Epistemologi Islam", dalam Jurnal Pemikiran dan Peradaban Islam Islamia, Thn. II, No. 5, April-Juni 2005. hlm. 9-20.

mimeralisasi Pemikiran Islam: Gerakan bersama Missionaris, Orientalis, dan Kolonialis, Ponorogo: Center for Islamic and Occidental studies (CIOS), 2008, Cet. I.

, Peradaban Islam: Makna dan Strategi Pembangunannya, Ponorogo: CIOS UNIDA, 2015. 